\title{
Extending the concept of the resource curse: Natural resources and public spending on health
}

\author{
Lara Cockxa and Nathalie Francken ${ }^{b}$
}

a LICOS - Centre for Institutions and Economic Performance

Waaistraat 6, Bus 3511, 3000 Leuven, Belgium
bIOB - Institute of Development Policy and Management, University of Antwerp
Prinsstraat 13, 2000 Antwerp, Belgium
LICOS - Centre for Institutions and Economic Performance
Waaistraat 6, Bus 3511, 3000 Leuven, Belgium
Department of Economics, Catholic University Leuven
Naamsestraat 69, 3000 Leuven, Belgium
Mail: nathalie.francken@uantwerpen.be

aCorresponding author: Lara Cockx c/o Nathalie Francken, LICOS, Waaistraat 6 Bus 3511, 3000 Leuven, Belgium, Tel.: +32 497944461; Mail: lara.cockx@kuleuven.be 


\section{ABSTRACT}

This paper extends the concept of the resource curse by studying whether and through which transmission channels natural resource wealth affects social spending. Even though the availability of vast natural capital reserves has commonly been linked to the neglect of human development, most of the literature has continued to focus on economic performance. This paper is the first to empirically investigate the link between natural resource wealth and public health expenditures in light of the hypothesis that resource wealth as a source of unearned state income enhances state autonomy and increases volatility, which leads to policies that fail to prioritize human development. Using a large panel dataset of world countries covering the period from 1995 to 2009, we find a robust, significant inverse relationship between natural resource dependence, and even abundance, and public health spending over time. The effect remains significant after controlling for state autonomy, volatility, and other factors. These findings have implications for national authorities as well as the extractive industry. Governments should be made accountable for natural resource wealth and correct taxation could provide additional resources, earmarked for health. The extractive industry could increase their investments in sustainable Corporate Social Responsibility operations, specifically in the health sector.

Key words: Natural resources, health, public spending, political economy JEL Classification: H750 O13 Q32 Q33 


\section{INTRODUCTION}

The paradox of natural resource wealth has inspired innumerous studies and continues to fascinate researchers across disciplinary boundaries. Even though the availability of vast natural capital has commonly been linked to the neglect of human development and the deterioration of institutions, most of the literature has continued to focus on the implications of the abundance of or dependence on natural resources on growth or other measures of economic performance. This paper aims at extending the concept of the resource curse and obtaining additional insights into the impact of resource wealth on government priorities and accountability. In particular it will add to the literature by contributing empirical insights on the link between resource wealth and human capital building.

The results of this research provide new input into the ongoing policy debate on innovative ways to channel natural resource revenues towards human development. This is particularly relevant as it has been observed that despite impressive growth accelerations in some resource-rich developing countries, human development indicators are still lagging behind. The World Bank (2013a) states that African countries that are experiencing strong economic growth from mineral revenues do not appear to have translated this wealth into improved health. Moreover, the 2013 African Progress Report notes that child malnutrition is endemic amongst African resource-rich countries and the levels of maternal mortality are well above average. Karl (2007) also mentions that despite significant rises in income, the living standards in oil-dependent countries have degraded over the past decades. Several scholars have established an adverse association between resource wealth and different health outcomes and the quality of health care provision. Take for example Angola, Sub-Saharan Africa's second-largest exporter of oil and the world's fifth-largest producer of diamonds, which is considered a "fragile state" (AFDB, 2009) and continuously performs well below regional averages with regards to health indicators. Even though the country has been making modest progress, the health system remains severely underdeveloped and while the rich enjoy highly subsidized private health care, the poor rural population lacks access to even the most rudimentary care (Africa Progress Panel, 2013). In order to tackle this perceived misalignment of resource wealth and human development and enable the population in resource-rich developing countries to truly profit from the opportunities provided by their vast natural resource endowments, it is important to investigate the intricate dynamics of the resource curse from a broader point of view.

We concentrate on health spending in particular, as there is an increasing consensus on the importance of health as a driver of sustainable economic growth (Barro, 2000). Moreover, the growth promoting benefits from health have been argued to be especially important for poor countries (Bhargava et al., 
2001). This seems to be reflected in the fact that on average public financing of health has risen sharply in developing countries and is expected to increase even further (Lu et al., 2010). The lower health expenditures in resource-rich countries therefore represent an important missed opportunity to use natural resource wealth to secure long term economic prosperity. Moreover, the importance of public health expenditures goes beyond the mere economic consequences, as it entails wide-ranging social implications and can be crucial in alleviating poverty (Gupta et al., 2003).

This paper focuses on inputs rather than health outcomes, as to grasp to what extent governments in resource-rich countries fail to prioritize policies geared towards the poor and human development. The results of this paper therefore also constitute a test for the hypothesized adverse effects of natural resources as a source of unearned state income that gives rise to autonomous and unaccountable states. To our knowledge, this paper is the first to empirically explore the impact of resource wealth on public health expenditures over time. We use a large panel dataset of world countries covering the period from 1995 to 2009 constructed for the aim of this research.

We find that both natural resource abundance and dependence are associated with lower public health spending as a percentage of GDP over time. We specifically take into account several transmission channels. We find evidence of an indirect effect of dependence and abundance through a deterioration of state accountability and volatility. The effect of resource dependence and abundance remains significant after controlling for several additional factors. Our findings have implications for national authorities as well as for the extractive industry and raise questions on innovative ways of channeling natural resource revenues towards human capital development.

The paper is organized as follows. The concept of the resource curse is depicted in Section 2. The third section describes the empirical specifications and the determinants of public health spending, including the transmission channels through which natural resource wealth could affect public health spending and additional control variables. The results and robustness tests are discussed in Section 4 and Section 5 concludes the paper. 


\section{THE CONCEPT OF THE RESOURCE CURSE}

It has been observed for some decades now that the possession of natural resources does not necessarily generate economic prosperity. On the contrary, it has almost become a conventional wisdom that resource wealth represents a curse rather than a blessing. Resource-rich African countries have often underperformed, while their resource-poor East-Asian counterparts are on the rise. The phrase "natural resource curse" was therefore coined by Auty (1994).

Pioneering empirical research from Sachs and Warner (1995) shows a significant inverse association between the ratio of natural resource exports to GDP and economic growth. Their results have been replicated by Davis (2013) and refined by numerous other authors, such as Gylfason et al. (1999), who emphasizes the likelihood of reduced investment in human capital. Auty (2001) finds that the per capita incomes of resource-poor countries grew between two to three times faster compared to their resourcerich counterparts. Neumayer (2004) concludes that the curse holds for "genuine income". Collier and Goderis (2007) demonstrate that while resource booms have a positive short-term impact on output, the effects for high-rent, non-agricultural commodities are negative in the long run. Papyrakis and Gerlagh (2004) find that the indirect adverse effects of natural resources on economic growth outweigh the direct positive effects. Van der Ploeg and Poelhekke (2011) show that the main effect of resource abundance is to increase growth volatility, which in turn reduces long-term growth. Other scholars focus on the role of rent-seeking (Torvik, 2002; Gylfason and Zoega, 2006) and corruption (Bhattacharyya and Hodler, 2010; Kasekende et al., 2014). The availability of natural resources has also been argued to make states more vulnerable to conflict (Collier and Hoeffler, 2003).

A general picture masks some variation. A minority of resource-rich countries seems to have fared extremely well, indicating that natural resources are no barrier to economic success. A great deal of literature attempts to explain this variation. Isham et al. (2005) find that "only countries dependent on point-source natural resources are subject to heightened economic and social divisions and weakened institutional capacity". Similarly, van der Ploeg and Poelhekke (2009) note that the detrimental volatility associated with the resource curse mainly stems from point-source resources. Mehlum et al. (2006) argue that the impact of natural capital on growth depends on the quality of institutions. Hodler (2006) finds that the effect of resource wealth on income is positive in homogeneous societies and becomes increasingly negative as ethnic fractionalization intensifies.

The evidence of the existence of the resource curse has been subject of debate. Criticism is mostly directed at the trade-based proxies for resource abundance, popularized by Sachs and Warner (1995). 
Brunnschweiler and Bulte (2008) argue that the ratio of natural resource exports to GDP is a measure of dependence rather than abundance. While this is a valid criticism, it doesn't imply that the resource curse doesn't hold. Rather it necessitates a clear distinction between resource dependence and abundance. Abundance indicates the amount of natural capital that a country has at its disposal, while dependence measures the extent to which a country relies on natural resources for its livelihood.

Typical examples of resource-rich countries with good economic performance, such as Canada and Norway, are often not dependent on them. Ding and Field (2005) show that while natural resource dependence has a significantly negative effect on growth rates, abundance appears to have a positive impact. Daniele (2011) finds that human development, measured by the human development index, is negatively affected by resource dependence, but positively by abundance. While we agree, that the effects of natural resource dependence and abundance may be markedly different in terms of magnitude and significance, we hypothesize that they affect public health expenditures in the same direction, as in this particular conception of the resource curse, abundance will set in motion largely the same dynamics as dependence.

Most of the literature has continued to focus on economic performance and empirical research on other effects of vast natural resource endowments is still scant. Bulte et al. (2005) find that "the resource curse appears to spill over from economic growth to a broader set of development indicators". Carmignani and Avom (2010) find that resource dependence has adverse effects on social development. The link between natural resources and inequality has been established by Gylfason and Zoega (2002), Fum and Hodler (2010), Goderis and Malone (2011) and Carmignani (2013). Gylfason $(1999,2001)$ demonstrates that school enrolment tends to be inversely related to resource abundance. He notes that in 2004 , on average public education and health spending in mineral-rich countries seemed to be considerably lower than their level of income might suggest (Gylfason, 2008). The author does not however, investigate the latter issue in-depth. Sarr and Wick (2010) studied the effect of resource wealth on the provision of public goods in authoritarian regimes and find evidence that indicates a negative effect on the availability of physical and social infrastructure. Bhattacharyya and Collier (2013) show a negative relationship between natural resource rents and public capital stock. Finally, de Soyza and Gizelis (2013) argue that oil wealth is associated with higher prevalence and mortality rates by HIV/AIDS. In line with this new wave of literature, this paper aims at extending the concept of the natural resource curse further by obtaining additional insights into the impact of resource wealth on public health spending. 


\section{EMPIRICAL SPECIFICATION AND VARIABLES}

We constructed a panel dataset for the period of 1995 to 2009 based on several internationally and scientifically recognized sources. In line with Brunschweiler and Bulte (2009), Bhattacharyya and Hodler (2010) and Bhattacharyya and Collier (2013), we have subdivided the data into three five year periods; from 1995 to 1999, from 2000 to 2004 and finally from 2005 to 2009. To tackle annual volatility and measurement errors we use five year averages. Descriptive statistics on the five year averages of all variables used in our analyses and discussed below are summarized in Table 1.

\subsection{Public health expenditures}

We use the World Bank data on public health expenditures as a percentage of GDP (Public Health Expenditures), which is derived from data from the World Health Organization. It consists of "recurrent and capital spending from government budgets, external borrowings and grants and social health insurance funds" (World Bank, 2014a). This spending therefore includes development assistance for health from government accounts as well as government health spending from domestic resources.

\section{Table 1}

\subsection{The determinants of public health spending}

\subsubsection{Natural resources}

While countries such as Botswana have shown that resource revenues can be harnessed for financing public goods such as health (Elovainio and Evans, 2013), the World Bank (2011) notes that natural resources may in general hinder the process of human capital creation that is the basis of long term growth. The availability of vast natural resource wealth can be argued to affect public expenditure on health in several ways. First of all, Gylfason (2001) states that the mere availability of natural capital in a country gives rise to a disregard for human capital development and myopic behaviour in general. Second, it has been argued that the source of revenue is an important determinant of public expenditures. In particular, Moore (2001) defines resource wealth as "unearned state income". Through natural resource extraction, governments are able to increase their autonomy. This disconnect could decrease the need to gain citizens' support, which consequently diminishes incentives to provide public goods such as health care. Resource-rich governments are most likely less dependent on tax revenues and politicians may therefore not feel the need to engage in public expenditures that justify taxes. 
Finally, resource revenues are often highly volatile, which complicates longer term planning and leads to boom and bust in public spending (Lane, 2003; van der Ploeg and Poelhekke, 2009).

In line with the criticism from Brunschweiler and Bulte (2008) and Lederman and Maloney (2008), we avoid using exports-based proxies. Rather, we use the estimates from the World Bank database on the Changing Wealth of Nations, which comprises a set of "comprehensive wealth accounts" for over 150 countries for 1995, 2000 and 2005 and contains estimations of natural capital that are reported in 2005 US dollars. Natural capital wealth is defined as the sum of the wealth ${ }^{1}$ stemming from crop, pasture land, timber and non-timber forest, protected areas, oil, natural gas, coal and minerals ${ }^{2}$.

\subsubsection{Natural resource dependence}

Natural resource dependence is of course predominantly determined by resource abundance, as this provides countries with a clear comparative advantage (Brunnschweiler and Bulte, 2008). However, the structural dependence on one sector and therefore the lack of economic diversification could to some extent already reflect the government's inability to effectively manage resource wealth. Moreover, perhaps the most effective way to deal with the detrimental volatility associated with commodities is diversification. It can therefore be expected that resource dependent economies will especially suffer from problems related to volatility.

In order to take into account a country's dependence on natural resources, we use the same measure as Gylfason (2001) and the World Bank (2011); the share of natural capital in total national wealth (Resource Dependence). The latter being defined here as the present value of future consumption that is sustainable, discounted at a rate of time preference of 1.5 per cent, over 25 years.

\subsubsection{Natural resource abundance}

We use the logarithm of the estimated natural capital per capita as a proxy for resource abundance (Resource Abundance) (see Brunschweiller and Bulte, 2009).

\subsubsection{Income}

There exists a large body of literature that shows income to be one of the most important determinants of public health expenditures (Lago-Peñas et al., 2013; Costa-Font et al., 2011; Clemente et al., 2004). It has been hypothesized that health care can even be considered to be a luxury good (Getzen, 2000).

\footnotetext{
1 The estimates are calculated as the net present value using a discount rate of 4 percent over a 25 year time horizon for renewable natural resources and over the time to exhaustion for the non-renewable natural resources.

2 Bauxite, copper, lead, nickel, phosphate, tin, zinc, gold, silver and iron ore.
} 
While most studies focus on OECD countries, Okunade (2005) and Murthy and Okunade (2009) confirm the importance of GDP for health expenditures in Africa.

We include the logarithm of the World Bank data on GDP per capita, reported in current US dollars, at the beginning of every five year period ${ }^{3}$ (GDP) (see Brunnschweiler and Bulte, 2009) as well as its square $\left(G P^{2}\right)$ to take into account a potential non-linear effect. It has been hypothesized that the relationship between income and health is concave (Deaton, 2003), so that income has a larger effect among the poor than among the rich. We therefore allow for a decreasing marginal effect of income on public health spending.

\subsubsection{Aid}

As income represents a crucial determinant of public health expenditures, supplements to income, such as foreign aid, are expected to relax macroeconomic budget constraints and increase resources for health care (Okunade, 2005). Moreover, often a substantial proportion of development assistance is targeted at the health sector and aims to shift government priorities. Murthy and Okunade (2009) demonstrate that aid is an important determinant of health care expenditures. It is important to note that part of development assistance for health is targeted at the non-governmental sector and is not reflected in the data on public health expenditures. Lu et al. (2010) however, find that development assistance for health to the non-governmental sector has a significantly positive effect on domestic government health spending.

To measure the impact of aid, we include five year averages of the World Bank data on one year-lagged net Official Development Assistance (ODA) received as a percentage of Gross National Income (GNI) $(\text { Aid })^{4}$. According to OECD definitions, ODA consists of "disbursements of loans made on concessional terms and grants by official agencies of the Development Assistance Committee (DAC) members, by multilateral institutions and by non-DAC countries to promote economic development and welfare" (World Bank, 2014b).

3 Using the five year averages rather than the initial level of income does not alter our main results. However, we find that the level of initial income is a better predictor of public health expenditures relative to GDP.

4 Repayments of the principal of loans are deducted to arrive at net ODA (DAC, 2008). We assume zero-values for countries not receiving aid. 


\subsubsection{Age distribution}

It can easily be argued that the age distribution of the population determines the demand for health care and subsequently health spending (di Matteo, 2005; Sen, 2005, Lago-Peñas et al., 2013). Traditionally, higher age is associated with more health care utilization ${ }^{5}$ (Yang et al., 2003; Dormont et al., 2006). Moreover, population ageing exerts an influence on the political prioritization, which could result in a demand for higher public health spending (Breyer et al., 2010). To control for the effect of age distribution on public health expenditures, we add the proportion of the total population aged 65 and above (Pop.>65) to our regression analysis. The data are gathered from the World Bank World Development Indicators (WDI) database.

The baseline empirical model is of the following form:

$$
\begin{aligned}
& \text { Public Health Expenditure }_{i t} \\
& =\beta_{0}+\beta_{1} \text { Resource Dependence }_{i t}+\beta_{2} G D P_{i t}+\beta_{3} G D P^{2}{ }_{i t}+\beta_{4} \text { Aid }_{i t}+\beta_{5}(\text { Pop. }>65)_{i t} \\
& +\alpha_{i}+\varepsilon_{i t}
\end{aligned}
$$

where i represents a country, $\mathrm{t}$ time, $\alpha$ the country fixed effect ${ }^{6}$ and $\varepsilon$ the error term. To investigate the effect of natural resource abundance, Resource Dependence is replaced by Resource Abundance.

\subsubsection{Transmission channels}

Besides the previously mentioned variables that can be argued to directly affect public health expenditures, the following transmission channels could play an important role in explaining the indirect effect of natural resources and will therefore be added to the empirical model.

\subsubsection{State autonomy and unaccountability}

According to the median voter theorem, in an accountable regime, policies reflect the median voter's preferences and will entail social sector support. The unaccountability of political leaders may on the contrary, give rise to opportunities for public agents to support rent generating sectors to the detriment of social sectors. Persson and Tabellini (2004) confirm that executive accountability influences the composition of government spending for a large sample of democracies. In particular, they conclude that more accountable regimes are associated with more public goods and larger welfare programs.

\footnotetext{
5 This assumption is not without dispute. It has been suggested that proximity to death represents the main determinant of health care costs (see for example Seshamani and Gray, 2004).

${ }^{6}$ The presence of country fixed effects is validated by the results of the Hausman test.
} 
Delavallade (2006) finds that "lack of freedom", which reflects unaccountability, is an important determinant of public sector spending and health expenditures in particular.

Several scholars have posited that the fiscal link between citizens and their government is a strong determinant of government accountability (Bates and Lien, 1985; North and Weingast, 1989, Moore, 2004). Arguably, governments that are able to derive their revenues from natural resources, face limited fiscal pressure from their citizens, which will consequently undermine accountability. Moore (2001) therefore introduced the idea of resource wealth as a source of "unearned state income" that gives rise to state autonomy and unaccountability, which subsequently influences public spending.

Next to this hypothesized adverse effect, we investigate whether the impact of natural resource wealth on public health spending is conditional on the degree of accountability. To this end, we study the interaction effects between resource dependence and abundance and state accountability (see Table 1, Appendix A).

We capture this transmission channel by including the Polity IV indicator on executive constraints. This variable refers to the extent of institutionalized constraints on the decision-making powers of chief executives. Limitations may be imposed by any "accountability groups", which are usually legislatures in Western democracies and a strong independent judiciary in many states. This measure captures the checks and balances between various parts of the decision-making process. The executive constraints measure contains numerical ratings based on a seven-category scale ranging from "unlimited authority" to "executive party of subordination" (Marshall et al., 2013). We refer to this measure as Accountability.

The empirical model which takes into account this particular transmission channel looks as follows:

$$
\begin{aligned}
& \text { Public Health Expenditures }_{i t} \\
& =\beta_{0}+\beta_{1} \text { Resource Dependence }_{i t}+\beta_{2} G D P_{i t}+\beta_{3} G D P^{2}{ }_{i t}+\beta_{4} \text { Aid }_{i t}+\beta_{5}(\text { Pop. }>65)_{i t} \\
& +\beta_{6} \text { Accountability }_{i t}+\alpha_{i}+\varepsilon_{i t}
\end{aligned}
$$

Including the interaction effect, the model is of the following form:

$$
\begin{aligned}
& \text { Public Health Expenditures }_{i t} \\
& =\beta_{0}+\beta_{1} \text { Resource Dependence }_{i t}+\beta_{2} G D P_{i t}+\beta_{3} G D P^{2}{ }_{i t}+\beta_{4} \text { Aid }_{i t}+\beta_{5}(\text { Pop. }>65)_{i t} \\
& +\beta_{6} \text { Accountability }_{i t}+\beta_{7} \text { Accountability }_{i t} * \text { Resource Dependence }_{i t}+\alpha_{i}+\varepsilon_{i t}
\end{aligned}
$$

where i represents a country, t time, $\alpha$ the country fixed effect 5 and $\varepsilon$ the error term. To investigate the effect of natural resource abundance, Resource Dependence is replaced by Resource Abundance. To study the impact of other proposed transmission channels, Accountability is replaced by Polity 2 , Volatility or Peace respectively. 


\subsubsection{Democracy}

Keefer and Khemani (2005) demonstrate that democracy enhances public service delivery, including health services, in particular to the poor. Natural capital and oil wealth specifically have often been associated with more autocratic regimes (Tsui, 2011; Ross, 2001). First of all, natural resource wealth is argued to increase competition for control of the state. Second, resource-rich authoritarian regimes are more likely to oppose democratic development because they will have more to give up from losing power (Acemoglu and Robinson, 2006). Finally, the unaccountability and autonomy associated with resource wealth has been argued to limit pressure for democratic change (Jensen and Wantchekon, 2004).

The level of democratization can therefore be considered as a transmission channel of the adverse impact of natural resource wealth on public health spending. The causality of the relationship between natural resource wealth and authoritarian regimes however, remains subject of debate (Haber and Menaldo, 2011; Alexeev and Conrad, 2009).

We include the Polity 2 score from the Polity IV dataset (Polity 2) which captures the regime authority spectrum on a 21-point scale ranging from minus ten, hereditary monarchy, to plus ten, consolidated democracy (CSP, 2013). As Bhattacharyya and Collier (2013) conclude that the negative impact of natural resources on the public capital stock is moderated by the quality of democracy, we include interaction terms to investigate this effect (see Table 1, Appendix A).

\subsubsection{Volatility}

Another commonly mentioned transmission channel of the resource curse that we consider as important with regards to the effect on public health spending is the volatile nature of resource revenues, mostly as a result of large fluctuations in the value of commodities. There are a number of difficulties that arise with a volatile source of income that lead to uncertainty over future financing and complicate longer term planning, which will affect public spending. Commodity price volatility also implies that it is not possible to protect government revenues derived from them in the long term (Elovainio and Evans, 2013). Moreover, it has been argued that revenue volatility induces a certain degree of myopic behaviour (Van der Ploeg and Poelhekke, 2009), which could give rise to a disregard for building human capital.

Again, we consider the possibility of a different effect of natural resources on public health spending conditional on the level of volatility by adding an interaction term to our regressions (see Table 1, Appendix A). 
Similar to Van der Ploeg and Poelhekke (2009), we base our measure of volatility on the standard deviation of growth in GDP per capita (pc). We define volatility as the standard deviation of GDP per capita growth from the 20-year country average applied to every five year period, similar to:

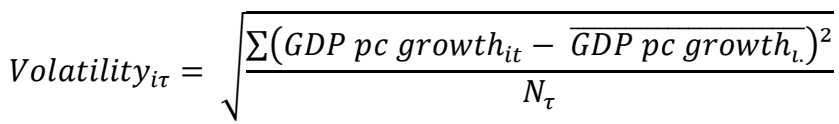

where i represents a country, $t$ time, $\mathrm{T}$ the five year period and $\mathrm{N}$ the number of observations.

\subsubsection{Conflict}

We also consider the role of conflict as it can be expected to alter government priorities and potentially influence public spending. Resource revenues are believed to provide both the motive and financing for armed conflict (Ross, 2006). The association between natural resources and the occurrence of conflict however, is still subject of debate (Basedau and Lay, 2009; Brunnschweiler and Bulte, 2009; Cotet and Tsui, 2013).

Based on the UCDP/PRIO armed conflict dataset, we derived a dummy variable (Conflict) that equals one in years where conflict is reported to take place in the country, and zero otherwise. Alternatively, we derived the years of peace (Peace), by counting the years in which no conflict was reported. We control for a potential interaction effect with natural resource wealth (see Table 1, Appendix A).

\subsubsection{Additional control variables ${ }^{7}$}

With the aim of testing the robustness of our results, we add variables that have been found to play an important role in explaining the resource curse and could affect public health spending.

A demographic factor that is sometimes mentioned in the resource curse literature (Hodler, 2006; Fum and Hodler, 2009) and has been found to be important in explaining government spending is ethnic fractionalization. "Fractionalized countries are argued to have lower levels of trust, more corruption, less transfers, subsidies and political rights" (Alesina et al., 2003), which could ultimately affect public social spending. Easterly and Levine (1997) report a strong negative correlation between ethnic fragmentation and the provision of public goods in African countries. Shelton (2008) finds that central government expenditures on health care are lower in countries with greater ethnic fractionalization. We control for this effect by adding an ethnic fractionalization index developed by Desmet et al. (2012).

\footnotetext{
In theory it could be argued that ELF1 and the regional dummies should be incorporated into the baseline model, but the nature of these particular variables would no longer allow us to conduct fixed effects regression analysis. We therefore opt to add them separately. The diversification of the primary sector and EITI membership on the other hand aren't expected to directly affect public health expenditure. The main reason for including these additional variables is in fact, to investigate the possibility of a mediating effect on the impact of natural resources. We therefore decided not to include them in our baseline regression specification.
} 
Fractionalization (ELF1) measures the probability that two randomly chosen individuals belong to different ethnic groups.

In line with Gylfason et al. (1999), Sala-i-Martin and Subramanian (2003), and Boschini et al. (2007), we also test our results by controlling for regional fixed effects. Mehlum et al. (2006) for example state that a potential concern is that "the resource curse mechanism might be purely an African phenomenon". We therefore introduce dummy variables for Africa and Asia to remove the influence of region-specific omitted factors. We explicitly take into account the possibility of a different impact of resource wealth by region by introducing interaction terms.

It has been argued that the effect of natural resources depends on the concentration of the production and revenue patterns (Isham et al., 2005; van der Ploeg and Poelhekke 2009). We therefore take into account the diversification of the primary sector by adding a Herfindahl index (Herfindah) to the regression. The index is calculated as the sum of squares of the shares of the different types of resources in total natural capital wealth. We explicitly investigate whether high sector dependence aggravates the resource curse effect on public health spending by including interaction effects.

Finally, in line with Kasekende et al. (2014) we consider the role of the Extractive Industries Transparency Initiative (EITI) by adding a dummy variable (EITI) that equals one when countries are either full EITI member or candidates. EITI partner countries are obliged to publicize tax revenues they receive from companies in the oil, gas and mining industries, thereby contributing to greater transparency between the extractive industry and the authorities with the aim of ultimately increasing accountability. Currently, there are 29 compliant countries and 16 candidate countries (EITI, 2014). We study the possibility of a mediating effect of EITI membership on the impact of natural resources by including an interaction effect. 


\section{RESULTS}

\subsection{Natural resource dependence}

\subsubsection{The impact of natural resource dependence on public health spending}

Before proceeding to the results, some remarks about the data analysis are in order. To check for collinearity, we applied the diagnostic tools developed by Belsley, Kuh and Welsch (1980) and find that the conditioning numbers are well below the suggested cut-off value of 30 , indicating that there are no problems with collinearity. We also report the results of the Hausman test, according to which rejection of the null hypothesis implies that the fixed effects model is to be preferred. Due to space constraints we limit ourselves to discussing the regressions that are deemed most suitable according to this test. To address any remaining within-country correlation, we use cluster-robust standard deviations. Finally, to identify outliers, we use the multivariate outlier detection method of Hadi $(1992,1994)$. The tables below display the results of the regressions applied to the entire sample as well as to the restricted sample.

\section{Table 2}

Table 2 summarizes our main results for natural resource dependence. We find evidence of a strong, statistically significant, negative relationship between natural resource dependence and public health spending relative to GDP, indicating the existence of a public health spending resource curse. We continue to find support for this hypothesized resource curse effect even after controlling for income, aid and age distribution. According to these estimations, keeping all other factors constant, a ten per cent increase in the share of natural capital in total national wealth (Resource Dependence), which corresponds for example to the difference between Bolivia (55.12\%) and Kuwait (65.31\%) in 2005, is associated with an average decrease of public health expenditures ranging from 0.1 to 0.2 per cent of GDP. Bearing in mind that the world average expenditure on health for this period was only 3.7 per cent of national GDP (World Bank, 2014a), this represents a considerable difference.

In line with the literature, our results reaffirm the hypothesized role of income in explaining health spending variation. In all but two of the regression specifications in Table 2, we find a significant coefficient for both the logarithm of initial GDP per capita (GDP) and its squared term (GDP2). We further note that a larger share of aid in GNI (Aid) is associated with higher public spending on health relative to GDP. Finally, in the baseline regression specification, the coefficient for the proportion of the population aged 65 and above (Pop.>65) is positive and highly significant; suggesting that age structure is an important determinant of public health spending. 
To test the robustness of our findings, we repeat the regressions excluding outliers. Except for Aid, all the variables remain significant and maintain the expected sign.

\subsubsection{Transmission channels}

Next, we investigate the role of the proposed transmission channels; accountability, democracy, volatility and conflict. The results from the fixed effects regressions including the proposed transmission channels are summarized in Table 3.

\section{$\underline{\text { Table } 3}$}

The Polity IV indicator on executive constraints (Accountability) is significant at the five per cent level. The positive coefficient implies that a higher score, which corresponds to more restrictions on executive actions and greater accountability, is associated with higher public health expenditures. Keeping all else fixed, a one point increase on the seven point scale of the executive constraints indicator, is associated with an increase in public health spending of over 0.1 per cent of GDP.

By adding the executive constraints indicator, the effect of Resource Dependence declines both in magnitude and significance. This could imply that natural resources affect public health expenditures through a deterioration of accountability and political institutions. We do not find support for the hypothesis that the impact of resource dependence alters conditional on the level of accountability in a country. When added to the regression the interaction effect is almost negligible in size and insignificant (see Table 1, Appendix A).

Next, we assess the role of democracy by including the Polity 2 score. The positive coefficient is significant only at the ten per cent level, both for the full and restricted sample. Keeping all else fixed a ten point increase on the Polity 2 score, which for example corresponds to a change from an autocratic regime to an anocracy, is associated with an increase in public health spending of 0.35 per cent of GDP. Again, we find no support of a conditional resource curse effect.

We further note that the coefficient for Volatility, measured as the standard deviation of growth in per capita GDP, is negative and significant at the one per cent level. Hence, it exerts a negative influence on public spending relative to GDP. This is as expected as volatility is bound to complicate longer-term planning and might induce a certain degree of shortsightedness. We find no indication however, that the magnitude of the impact of natural resource dependence differs depending on the degree of volatility as there is no significant interaction effect (see Table 1, Appendix A). 
The results do not indicate that conflict is a significant determinant of public expenditures on health. ${ }^{8}$ While our results confirm the role of years of peace (Peace) as a positive determinant of public health spending for the entire sample, the effect is not robust to excluding outliers. We don't find any evidence for the hypothesis that the effect of natural resources alters conditional on the years of peace.

We conclude that the results strongly suggest that unaccountability and volatility act as main transmission channels of the adverse impact of natural resource dependence on public health spending. We find no support for any conditional resource curse effect. In sum, we derive the following model to investigate the overall effect of the main transmission channels:

$$
\begin{aligned}
& \text { Public Health Expenditures }_{i t} \\
& =\beta_{0}+\beta_{1} \text { Resource Dependence }_{i t}+\beta_{2} G D P_{i t}+\beta_{3} G D P^{2}{ }_{i t}+\beta_{4} \text { Aid }_{i t}+\beta_{5}(\text { Pop. }>65)_{i t} \\
& +\beta_{6} \text { Accountability }_{i t}+\beta_{7} \text { Volatility }_{i t}+\alpha_{i}+\varepsilon_{i t}
\end{aligned}
$$

where i represents a country, $\mathrm{t}$ time, $\alpha$ the country fixed effect ${ }^{5}$ and $\varepsilon$ the error term.

Interestingly, adding the variables on both main transmission channels renders the effect of Resource Dependence insignificant for the entire sample. While it remains significant at the five per cent level when excluding outliers, the great reduction in the magnitude of the effect suggests that at least part of the impact of natural resource dependence on public health spending relative to GDP can be attributed to problems related to state unaccountability and volatility.

To estimate the indirect effects of natural resource dependence, we apply the method from Papyrakis and Gerlagh (2004). First, we estimate the effect of natural resource dependence on accountability and volatility:

$$
\begin{aligned}
& \text { Accountability }_{i t}=\gamma_{0}+\gamma_{1} \text { Resource Dependence }_{i t}+\varphi_{i}+\mu_{i t} \\
& \text { Volatility }_{i t}=\delta_{0}+\delta_{1} \text { Resource Dependence }_{i t}+\omega_{i}+\theta_{i t}
\end{aligned}
$$

where i represents a country, t time, $\varphi$ and $\omega$ the country fixed effects ${ }^{5}$ and $\mu$ and $\theta$ the error terms.

Substituting equations 5, 6 and 7 into equation 1 yields:

$$
\begin{aligned}
& \text { Public Health Expenditures }_{i t} \\
& =\beta_{0}+\left(\gamma_{0} * \beta_{6}+\delta_{0} * \beta_{7}\right)+\left[\beta_{1}+\left(\gamma_{1} \beta_{6}+\delta_{1} \beta_{7}\right)\right] \text { Resource Dependence }_{i t}+\beta_{2} G D P_{i t} \\
& +\beta_{3} G D P^{2}{ }_{i t}+\beta_{4} \text { Aid }_{i t}+\beta_{5}(\text { Pop. }>65)_{i t}+\alpha_{i}+\left(\beta_{6} \varphi_{i}+\beta_{7} \omega_{i}\right)+\varepsilon_{i t}+\left(\beta_{6} \mu_{i t}+\beta_{7} \theta_{i t}\right)
\end{aligned}
$$

where $\beta_{1}$ Resource Dependence $_{i t}$ is the direct effect of resource dependence on public spending on health and $\left(\gamma_{1} \beta_{6}+\delta_{1} \beta_{7}\right)$ Resource Dependence $e_{i t}$ the indirect effect through a deterioration of accountability and volatility respectively.

\footnotetext{
${ }^{8}$ Additional information can be obtained from the corresponding author upon request.
} 
We find that this indirect effect explains about 12 per cent of the total adverse effect of Resource Dependence on Public health Expenditures.

\subsubsection{Additional control variables}

We find limited support for an adverse effect of ethnic fractionalization, as measured by $E L F 1$, on public health expenditures relative to $\mathrm{GDP}^{9}$ (see Table 4). Our main results remain robust.

\section{Table 4}

In order to investigate potential regional effects, we introduce dummy variables for Africa and Asia. As the latter are time invariant, we use a random effects regression model (see Table 4). Our results indicate that Asian countries spend on average up to one per cent of GDP less on public health compared to the rest of the world. There is some evidence that the health spending resource curse is stronger in Africa, as the interaction effect between Africa and Resource Dependence is significantly negative when excluding outliers (see Table 2, Appendix A).

Our results don't show a significant main effect of the diversification of the primary sector ${ }^{8}$, as measured by the Herfindahl index. Nor do we find evidence of an interaction with resource dependence. Finally, we investigate the role of EITI. Given EITI's short existence, a panel regression is no longer feasible and we conduct an Ordinary Least Squares (OLS) regression for the period of 2005 to 2009. We find no support for a positive effect of EITI membership on public health spending (see Table 3, Appendix A), nor do the results indicate a mediating effect on the impact of resource dependence. ${ }^{10}$

\subsection{Natural resource abundance}

\subsubsection{The impact of natural resource abundance on public health spending}

As aforementioned, it is important to differentiate between resource dependence and abundance, as there are countries that are highly dependent on natural resources while the latter are not abundantly available and vice versa.

As the ethnolinguistic fractionalization index displays little variation over time, the within estimator is no longer appropriate and we apply a random effects regression.

10 This is however not surprising as the EITI is still a new concept. Moreover, questions are rising about the effectiveness of this mechanism and its current regulations (Kolstad and Wiig, 2009; Ölcer, 2009). Pitlik et al. (2010) and Kasekende et al. (2014) have also demonstrated that EITI membership is prone to self-selection bias as the initiative mostly attracts poor countries with a marked corruption problem. 
Take for example Chad, a country that is estimated to obtain up to 90 percent of its wealth from natural resources, while according to World Bank estimations its per capita natural capital falls well below the median. Moreover, Chad's public health spending relative to GDP has consistently been below the regional average. On the contrary, countries such as Norway, Australia and Canada, where natural capital contributes to less than ten per cent of total wealth and that are known to have high public expenditures on health, are endowed with the largest natural capital reserves in the world. We therefore repeat the regressions using the logarithm of total natural capital per capita as a measure for resource abundance. The results are summarized in Table 5.

\section{Table 5}

We find strong support for a health spending resource curse effect of the mere availability of natural capital. The negative coefficient for Resource Abundance is significant at the five per cent level for all regression specifications. Perhaps most important for the purpose of this paper, controlling for income, aid and age distribution doesn't alter the significance or the magnitude of the adverse effect of Resource Abundance. According to our baseline regression specification, keeping all else fixed, a ten per cent increase in natural capital per capita, which for example corresponds roughly to the difference between Angola (13306.6 USD) and the Republic of Congo (14679.44 USD) in 2005, is associated with an average decrease of public expenditures on health ranging from 0.04 to 0.05 per cent of GDP.

Other coefficients also seem to be plausibly estimated and are similar to what we found for the regressions including Resource Dependence. While we find rather limited support for the non-linear relationship between the initial level of GDP per capita and public health expenditures, income clearly is an important positive determinant of public health spending. The share of ODA in GNI (Aid) has a highly significant positive effect on public health expenditures. Finally, our results strongly confirm that an ageing population leads to higher public expenditure on health.

\subsubsection{Transmission channels}

We investigate the role of the proposed transmission channels in explaining the effect of resource abundance. We find that a higher score with regards to executive constraints, which is associated with more accountability, corresponds to higher public health spending. The highly significant, negative coefficient for the standard deviation of per capita growth (Volatility), once more suggests that volatility is a negative determinant of public health spending. We further demonstrate that the positive effect of Polity 2 is significant at the five per cent level. The results don't show a significant effect of conflict?. 
The coefficient for years of peace (Peace) is significantly positive only for the restricted sample. We find no significant interaction effects (see Table 1, Appendix A).

\section{$\underline{\text { Table } 6}$}

To investigate the overall effect of the main transmission channels ${ }^{11}$ and in line with equation (5), we estimate the model including both the executive constraints indicator (Accountability) and the standard deviation of per capita growth (Volatility).

Similar to our previous findings related to dependence, we observe a slight reduction in the magnitude of the effect of Resource Abundance when including both proposed main transmission channels. The effect however, remains significant at the five per cent level. When calculating the direct and indirect effects of natural resource abundance according to the method of Papyrakis and Gerlagh (2004), we find that the main transmission channels' indirect effect accounts for approximately 15 per cent of the overall effect of Resource Abundance on Public Health Expenditures.

\subsubsection{Additional control variables}

The regression results (see Table 7) show a significantly negative effect of ethnic fractionalization (ELF1) on public health spending relative to GDP for the entire sample. Excluding the outliers, the results of the regression analysis of the restricted sample confirm the hypothesized negative effect of natural resource abundance on public health spending.

\section{$\underline{\text { Table } 7}$}

Our results confirm that public health expenditures are significantly lower in Asia compared to the rest of the world. Moreover, the negative effect of resource abundance on public health expenditures is found to be significantly stronger in Africa as well as in Asia (see Table 2, Appendix A).

Finally, we find no support for the role of diversification of the primary sector ${ }^{8}$. The results of the OLS regression for the period of 2004 to 2009, don't show a significant coefficient for EITI, nor do we find evidence of a mediating effect on the impact of natural resource abundance (see Table 3, Appendix A).

11 We note that the Polity 2 index is based on the executive constraints indicator. Adding both variables to the regression is therefore deemed unsuitable because of their high correlation. 


\subsection{Robustness checks}

\subsubsection{Time fixed effects}

To test the robustness of our results, we add time fixed effects to our baseline regression model. As such, we control for unobserved effects that vary over time as well as over countries. The results are summarized in Table 8.

\section{Table 8}

In line with the findings of Lu et al. (2010), we note that the time dummies are highly significant and indicate a general increasing trend in public health expenditures relative to GDP over time. The adverse effect of both natural resource dependence and abundance however, is robust to controlling for time fixed effects as they decrease neither in magnitude nor in significance. Interestingly, the effect of aid dependency on public health expenditures appears to be considerably larger in terms of magnitude as well as significance. To the extent that the time period dummies reflect omitted variables, this suggests that our previous results for the effect of aid could be biased downwards. The impact of age structure on the other hand, is no longer statistically significant. This is however in line with our expectations as changes in the share of the population aged 65 and above mostly reflect general trends over time.

\subsubsection{Public health expenditures relative to government expenditures}

As a final robustness check, we verify whether the curse holds with a different measure of health spending by applying our baseline regression model to public health expenditures relative to total government expenditures ${ }^{12}$.

\section{$\underline{\text { Table } 9}$}

The results of the regression analysis of the restricted sample, excluding outliers, confirm the hypothesized negative effect of both resource dependence and abundance on public health spending as percentage of government expenditures.

12 We prefer to use public health expenditures relative to GDP in our main analyses as by using public health expenditures relative to government expenditures, we lose information on the size of the government. Moreover, introducing total government spending in the denominator of our indicator renders our results sensitive to the evolution of other types of government spending, including military expenditures. This could potentially distort results, especially in the presence of conflict. 


\section{CONCLUSIONS}

This paper contributes to the literature on the resource curse by empirically investigating how natural resource wealth affects public health spending. Little attention has been paid to this matter so far, while research indicates that health care is crucial to building human capital and securing sustainable economic growth. This is especially important for developing countries as improving the health status of their citizens could substantially ameliorate their economic performance. Moreover, it has been shown that public spending on health care matters more for the poor in general (Gupta et al., 2003). Finally, this paper is innovative as it examines the effects of natural resources on inputs rather than human development outcomes as the latter might reflect factors beyond policymakers' control.

We study the impact of natural resources on public health expenditures relative to GDP in light of the hypothesis that the availability of resource wealth as a source of unearned state income enhances state autonomy and volatility, which leads to policies that fail to prioritize human development. We find a robust, significant inverse relationship between natural resource dependence and public health spending relative to GDP. Moreover, we find that part of this adverse effect can be attributed to the proposed transmission channels of state accountability and volatility. The effect of resource dependence remains significant even after controlling for other variables such as income, aid, the age structure of the population, the level of democratization, conflict, ethnic fractionalization and regional effects. Furthermore, our regression results show that the mere availability of natural resources (or resource abundance) has a significantly negative effect on public health expenditures relative to GDP. While this effect appears to be slightly less robust than the relationship between resource dependence and public health expenditure, it remains significant when adding most of the additional control variables.

The establishment of the existence of a resource curse effect on public health expenditures underlines the importance of government accountability and transparency with regards to natural resource wealth. While we find no evidence of a mediating effect so far, the best instrument currently being promoted for ensuring greater transparency is the EITI. Governments should be made accountable for resource wealth, not only through transparent declaration, but also correct taxation and redistribution of natural resource capital. Following our findings, a substantial part of the tax revenues could for example be earmarked for the health sector. Our results also urge the extractive industry to invest in sustainable Corporate Social Responsibility operations, especially in the health sector and/or to increase health funding through other innovative channels of development finance. 


\section{ACKNOWLEDGEMENTS}

The authors would like to thank two anonymous reviewers for their constructive comments. We also extend our gratitude to the participants of the Institute of Development Policy and Management (IOB) at the University of Antwerp and the Centre for Institutions and Economic Performance (LICOS) at the University of Leuven seminars, the 2014 Centre for the Study of African Economies (CSAE) conference on Economic Development in Africa at Oxford University and the $15^{\text {th }} \mathrm{PhD}$ symposium on Agricultural and Natural Resource Economics in Brussels for their useful suggestions. This research has been partly financed with Methusalem Funding, DOE-B9549-Meth/08/01. 


\section{REFERENCES}

Acemoglu, D. , Robinson, J.A. 2006. Economic origins of dictatorship and democracy. Cambridge:

Cambridge University Press.

http://dx.doi.org/10.1017/CBO9780511510809

Africa Progress Panel 2013. Equity in extractives. Africa Progress Panel. Africa Progress Report 2013: Geneva.

African Development Bank. 2009. CPIA ratings and related indicators: Angola. Available at $<$ http://cpia.afdb.org/Reports.aspx> (Accessed 12 July 2014).

Alesina, A., Devleeschauwer, A., Easterly, W. Kurlat, S., Wacziarg, R. 2003. Fractionalization. Journal of Economic Growth 8(2): 155-194.

http://dx.doi.org/10.1023/A:1024471506938

Alexeev, M., \& Conrad, R. (2009). The elusive curse of oil. The Review of Economics and Statistics, 91(3), 586-598.

http://dx.doi.org/10.1162/rest.91.3.586

Auty, R. M. 1994. Industrial policy reform in six large newly industrializing countries: The resource curse thesis. World development 22(1): 11-26.

http://dx.doi.org/10.1016/0305-750X(94)90165-1

Auty, R.M. 2001. Resource abundance and economic development. Oxford: Oxford University Press. http://dx.doi.org/10.1093/0199275785.001.0001

Barro, R.J. 2000. Education and economic growth. In OECD (Organization for Economic Cooperation and Development) Symposium on the contribution of human and social capital to sustainable economic growth and well-being. Québec City, Canada, 19-21 March 2000.

Bates, R.H., Lien D.H.D. 1985. A note on taxation, development and representative government. Politics Society 14(53): 53-70.

http://dx.doi.org/ 10.1177/003232928501400102

Basedau, M., \& Lay, J. 2009. Resource curse or rentier peace? The ambiguous effects of oil wealth and oil dependence on violent conflict. Journal of Peace Research 46(6): 757-776.

http://dx.doi.org/10.1177/0022343309340500 
Belsley, D.A., Kuh, E., Welsch, R.E. 1980. Regression diagnostics: Identifying influential data and sources of collinearity. John Wiley and Sons: New Jersey.

http://dx.doi.org/10.1002/0471725153

Bhargava, A., Jamison, D.T., Lau, L.J., Murray, C.J.L. 2001. Modeling the effects of health on economic growth. Journal of Health Economics 20(3): 423-440.

http://dx.doi.org/10.1016/S0167-6296(01)00073-X

Bhattacharyya, S., Hodler, R. 2010 Natural resources, democracy and corruption. European Economic Review 54(4): 608-621.

http://dx.doi.org/10.1016/j.euroecorev.2009.10.004

Bhattacharyya, S., \& Collier, P. 2013. Public capital in resource rich economies: is there a curse?. Oxford Economic Papers.

doi:10.1093/oep/gps073

Billor, N., Hadi, A. S., \& Velleman, P. F. 2000. BACON: blocked adaptive computationally efficient outlier nominators. Computational Statistics \& Data Analysis 34(3): 279-298.

http://dx.doi.org/10.1016/S0167-9473(99)00101-2

Boschini, A.D., Pettersson, J., Roine, J. 2007. Resource curse or not : A question of appropriability. The Scandinavian Journal of Economics 109(3): 593-617.

http://dx.doi.org/10.1111/j.1467-9442.2007.00509.x

Breyer, F., Costa-Font, J., \& Felder, S. (2010). Ageing, health, and health care. Oxford Review of Economic Policy 26(4): 674-690.

http://dx.doi.org/10.1093/oxrep/grq032

Brunnschweiler, C.N., Bulte, E.H. 2008. The resource curse revisited and revised: a tale of paradoxes and red herrings. Journal of Environmental Economics and Management 55(3): 248-264.

http://dx.doi.org/10.1016/j.jeem.2007.08.004

Brunnschweiler, C.N., Bulte, E.H. 2009. Natural resources and violent conflict: Resource abundance, dependence and the onset of civil war. Oxford Economic Papers 61(4):651-674.

http://dx.doi.org/10.1093/oep/gpp024 
Bulte, E., Damania, R., Deacon, R. 2005. Resource intensity, institutions, and development. World Development 33(7): 1029-1044.

http://dx.doi.org/10.1016/j.worlddev.2005.04.004

Carmignani, F., Avom, D. 2010. The social development effects of primary commodity export dependence. Ecological Economics 70(2):317-330.

http://dx.doi.org/10.1016/j.ecolecon.2010.09.003

Carmignani, F. 2013. Development outcomes, resource abundance, and the transmission through inequality. Resource and Energy Economics 35(3): 412-428.

http://dx.doi.org/10.1016/j.reseneeco.2013.04.007

Centre for Systemic Peace 2013. Polity IV Project : Political regime characteristics and transitions, 1800-2012. Available at <http://www.systemicpeace.org/polity/polity4.htm> (Accessed 20 July 2013).

Clemente, J., Marcuello, C., Montañés, A., Pueyo, F. 2004. On the international stability of health care expenditure functions: are government and private functions similar?. Journal of Health Economics 23(3): 589-613.

http://dx.doi.org/10.1016/j.jhealeco.2003.08.007

Collier, P., Goderis, B. 2007. Commodity prices, growth, and the natural resource curse: reconciling a conundrum. Centre for the Study of African Economies Working Paper No.274: Oxford. http://dx.doi.org/10.2139/ssrn.1473716

Collier, P., Hoeffler, A. 2003. Aid, Policy, and Peace: reducing the risks of civil conflict. Defense and Peace Economics 13 (6): 435-450.

http://dx.doi.org/10.1080/10242690214335

Costa-Font, J., Gemmill, M., Rubert, G. 2011. Biases in the healthcare luxury good hypothesis?: a metaregression analysis. Journal of the Royal Statistical Society 147(1): 95-107.

http://dx.doi.org/10.1111/j.1467-985X.2010.00653.x

Cotet, A.M., Tsui, K.K. 2013. Oil and Conflict: What Does the Cross Country Evidence Really Show?. American Economic Journal 5(1): 49-80.

http://dx.doi.org/10.1257/mac.5.1.49 
Daniele, V. 2011. Natural resources and the quality of development. Journal of Development Studies 47(4): 545-573.

http://dx.doi.org/10.1080/00220388.2010.506915

Davis, G.A. 2013. Replicating Sachs and Warner's working papers on the resource curse. Journal of Development Studies 49(12): 1615-1630.

http://dx.doi.org/10.1080/00220388.2013.807501

Deaton, A. 2003. Health, inequality, and economic development. Journal of Economic Literature 41(1): 113-158.

http://dx.doi.org/10.1257/002205103321544710

Delavallade, C. 2006. Corruption and distribution of public spending in developing countries. Journal of Economics and Finance 30(2): 222-239.

http://dx.doi.org/10.1007/BF02761488

Desmet, K., Ortin, I., Wacziarg, R. 2012. The political economy of linguistic cleavages. Journal of Development Economics 97(2): 322-338.

http://dx.doi.org/10.1016/j.jdeveco.2011.02.003

De Soyza,I., Gizelis, T.I. 2013. The natural resource curse and the spread of HIV/AIDS, 1990-2008. Social Science and Medicine 77: 90-96.

http://dx.doi.org/10.1016/j.socscimed.2012.11.010

Development Assistance Committee 2008. Is it ODA?. OECD-DAC Fact Sheet-November 2008.

Di Matteo, L. 2005. The macro determinants of health expenditure in the United States and Canada: assessing the impact of income, age distribution and time. Health Policy 71(1): 23-42.

http://dx.doi.org/10.1016/j.healthpol.2004.05.007

Ding, N., \& Field, B. C. (2005). Natural Resource Abundance and Economic Growth. Land Economics 81(4): 496-502.

http://dx.doi.org/10.2139/ssrn.564567

Dormont, B., Grignon, M., \& Huber, H. (2006). Health expenditure growth: reassessing the threat of ageing. Health economics 15(9): 947-963.

http://dx.doi.org/10.1002/hec.1165 
Easterly, W., \& Levine, R. (1997). Africa's growth tragedy: policies and ethnic divisions. The Quarterly Journal of Economics 112(4): 1203-1250.

http://dx.doi.org/10.1162/003355300555466

Elovainio, R., \& Evans, D. 2013. Raising and spending domestic money for health. Centre for global health working group papers: working group on financing paper 2.

Fum, R.M., Hodler, R. 2010. Natural resources and income inequality: the role of ethnic divisions.

Economics Letters 107(3): 360-363.

http://dx.doi.org/10.1016/j.econlet.2010.03.008

Getzen, T.E. 2000. Health care is an individual necessity and a national luxury: applying multilevel decision models to the analysis of health care expenditures. Journal of Health Economics 19(2):259270.

http://dx.doi.org/10.1016/S0167-6296(99)00032-6

Gleditsch, N.P., Wallensteen,P., Eriksson,M., Sollenberg, M. , Strand,H. 2002. Armed Conflict 19462001: A New Dataset. Journal of Peace Research 39(5): 615-637.

http://dx.doi.org/10.1177/0022343302039005007

Goderis, B., Malone, S.W. 2011. Natural Resource Booms and Inequality: Theory and Evidence. The Scandinavian Journal of Economics 113(2): 388-417.

http://dx.doi.org/10.1111/j.1467-9442.2011.01659.x

Gupta, S., Verhoeven, M., Tjongson, E.R. 2003. Public spending on health care and the poor. Health Economics 12(8): 685-696.

http://dx.doi.org/10.1002/hec.759

Gylfason, T., Herbertsson, T.T., Zoega, G. 1999.A mixed blessing. Macroeconomic Dynamics 3(2): 204-225.

http://dx.doi.org/10.1017/S1365100599011049

Gylfason, T. 2001. Natural resources, education, and economic development. European Economic Review 45(4-6): 847-859.

http://dx.doi.org/10.1016/S0014-2921(01)00127-1

Gylfason, T. 2008. Development and growth in mineral-rich countries. CEPR Discussion Paper 7031 
Gylfason, T., Zoega, G. 2002. Inequality and economic growth: do natural resources matter?. Center for Economic Studies CESifo Working Paper 712 (5).

Gylfason, T., Zoega, G. 2006. Natural resources and economic growth: the role of investment. The World Economy 29 (8): 1091-1115.

http://dx.doi.org/10.1111/j.1467-9701.2006.00807.x

Haber, S., \& Menaldo, V. 2011. Do natural resources fuel authoritarianism? A reappraisal of the resource curse. American Political Science Review 105(01): 1-26.

Hadi, A.S. 1992. Identifying multiple outliers in multivariate data. Journal of the Royal Statistical Society 54(3): 761-771.

Hadi, A.S. 1994. A Modification of a Method for the Detection of Ouliers in Multivariate Samples. Journal of the Royal Statistical Society 56(2): 393-396.

Hodler, R. 2006. The curse of natural resources in fractionalized countries. European Economic Review 50(6): 1367-1386.

http://dx.doi.org/10.1016/j.euroecorev.2005.05.004

Isham, J., Woolcock, M., Pritchett, L., Busby, G. (2005) "The varieties of resource experience: natural resource export structures and the political economy of economic growth", World Bank Economic Review, 19(2): 141-174.

http://dx.doi.org/10.1093/wber//hi010

Jensen, N., \& Wantchekon, L. 2004. Resource wealth and political regimes in Africa. Comparative political studies 37(7): 816-841.

http://dx.doi.org/10.1177/0010414004266867

Karl, T.L. 2007. Oil-Led Development: Social, Political, and Economic Consequences. Stanford Center on Democracy, Development and the Rule of Law Working Paper 80.

Kasekende, E., Abuka, C., Sarr, M. 2014. Extractive industries and corruption: An investigation into the effectiveness of EITI as a scrutiny mechanism, working paper for presentation at the Centre for African Economies Conference, UK, March 2014.

Keefer, P., Khemani, S. 2005. Democracy, Public Expenditures and the Poor: Understanding Political Incentives for Providing Services. World Bank Research Observer 20(1): 1-27.

http://dx.doi.org/10.1093/wbro//ki002 
Kolstad, I., \& Wiig, A. 2009. Is transparency the key to reducing corruption in resource-rich countries?. World Development, 37(3), 521-532.

Lago-Peñas, S., Cantarero-Prieto, D., \& Blázquez-Fernández, C. 2013. On the relationship between GDP and health care expenditure: a new look. Economic Modelling 32: 124-129.

http://dx.doi.org/10.1016/j.econmod.2013.01.021

Lane, P. R. 2003. The cyclical behaviour of fiscal policy: evidence from the OECD. Journal of Public Economics 87(12): 2661-2675.

http://dx.doi.org/10.1016/S0047-2727(02)00075-0

Lederman, D., Maloney, W.F. 2008. In search of the missing resource curse. Economia 9(1): 1-57.

Lu, C., Schneider, M. T., Gubbins, P., Leach-Kemon, K., Jamison, D., Murray, C. J. (2010). Public financing of health in developing countries: a cross-national systematic analysis. The Lancet 375(9723): 1375-1387.

http://dx.doi.org/10.1016/S0140-6736(10)60233-4

Marshall, M.G., Gurr, T., Jaggers, K. 2013. Political Regime Characteristics and Transitions, 1800-2012: Dataset Users' Manual. Center for Systemic Peace.

Mehlum, J., Moene, K., Torvik, R. 2006. Institutions and the resource curse. The Economic Journal 116(508): 1-20.

http://dx.doi.org/10.1111/j.1468-0297.2006.01045.x

Moore, M. 2001. Political underdevelopment: what causes 'bad governance'. Public Management Review 3(3): 385-418.

http://dx.doi.org/10.1080/14616670110050020

Moore, M. 2004. Revenues, state formation, and the quality of governance in developing countries. International Political Science Review 25(3): 297-319.

http://dx.doi.org/10.1177/0192512104043018

Murthy, V.N.R., Okunade, A.A. 2009. The core determinants of health expenditure in the African context: Some econometric evidence for policy. Health Policy 91(1): 57-62.

http://dx.doi.org/10.1016/j.healthpol.2008.10.001 
Neumayer, E. 2004. Does the resource curse hold for growth in genuine income as well?. World Development 32(10): 1627-1640.

http://dx.doi.org/10.1016/j.worlddev.2004.05.005

North, D. C., \& Weingast, B. R. 1989. Constitutions and commitment: the evolution of institutions governing public choice in seventeenth-century England. The journal of economic history 49(04): 803832.

http://dx.doi.org/10.1017/S0022050700009451

Okunade, A.A. 2005. Analysis and Implications of the Determinants of Healthcare Expenditure in African Countries. Health Care Management Science 8(4): 267-276.

http://dx.doi.org/10.1007/s10729-005-4137-5

Ölcer, D. 2009. Extracting the Maximum from the EITI . OECD Development Centre Working Paper No. 276. OECD Publishing.

Papyrakis, E., Gerlagh, R. 2004. The resource curse hypothesis and its transmission channels. Journal of Comparative Economics 32(1): 181-193.

http://dx.doi.org/10.1016/j.jce.2003.11.002

Persson, T., \& Tabellini, G. 2004. Constitutional rules and fiscal policy outcomes. American Economic Review 94(1): 25-45.

http://dx.doi.org/10.1257/000282804322970689

Pitlik, H., Frank, B., \& Firchow, M. 2010. The demand for transparency: an empirical note. The Review of International Organizations 5(2): 177-195.

Ross, M. L. (2001). Does oil hinder democracy?. World politics 53(03): 325-361.

http://dx.doi.org/10.1353/wp.2001.0011

Ross, M.L. 2003. The natural resource curse: how wealth can make you poor. In P. Collier, M. Bannon, eds. 2003 Natural resources and violent conflict. Washington D.C.: World Bank. 17-42.

Ross, M. L. 2006. A closer look at oil, diamonds, and civil war. Annual Review of Political Science 9: 265-300.

http://dx/doi.org/ 10.1146/annurev.polisci.9.081304.161338

Sachs, J.D., Warner, A.M. 1995. Natural resource abundance and economic growth. National Bureau of Economic Research Working paper n ${ }^{\circ} 5398$. 
Sala-i-Martin, X., Subramanian, A. 2003. Addressing the natural resource curse: evidence from Nigeria. International Monetary Fund Working Paper No. 139.

Sarr, M., \& Wick, K. 2010. Resources, conflict and development choices: public good provision in resource rich economies. Economics of Governance 11(2): 183-205.

http://dx.doi.org/10.1007/s10101-010-0075-x

Sen, A. 2005. Is health care a luxury? New evidence from OECD data. International Journal of Health Care Finance and Economics 5(2): 147-164.

http://dx.doi.org/10.1007/s10754-005-1866-4

Seshamani, M., \& Gray, A. 2004. Ageing and health-care expenditure: the red herring argument revisited. Health economics 13(4): 303-314.

http://dx.doi.org/10.1002/hec.826

Shelton, C.A. 2008. The Aging Population and the Size of the Welfare State: Is There a Puzzle?. Journal of Public Economics 92(3-4): 647-651.

http://dx.doi.org/10.1016/j.jpubeco.2007.10.002

Torvik, R. 2002. Natural resources, rent seeking and welfare. Journal of Development Economics 67(2): 455-470.

http://dx.doi.org/10.1016/S0304-3878(01)00195-X

Tsui, K. K. 2011. More oil, less democracy: Evidence from worldwide crude oil discoveries. The Economic Journal 121(551): 89-115.

http://dx.doi.org/10.1111/j.1468-0297.2009.02327.x

Van der Ploeg, F., Poelhekke, S. 2009. Volatility and the resource curse. Oxford Economic Papers 61(4): 727-760.

http://dx.doi.org/10.1093/oep/gpp027

Van der Ploeg, F. Poelhekke, S. 2011. Natural resources: Curse or blessing?. Journal of Economic Literature 49(2): 366-420.

World Bank 2010. Changing Wealth of Nations. Available at < http://data.worldbank.org/datacatalog/wealth-of-nations> (accessed 16 August 2013)

World Bank. (2011). The Changing Wealth of Nations: Measuring Sustainable Development in the New Millennium. World Bank, Washington D.C. 
World Bank 2013a. Africa Health Forum : Finance and capacity for results. Washington D.C., United States, 18 April 2013.

World Bank 2014a. Health Expenditure, public (\% of GDP). Available at $<$ <ttp://data.worldbank.org/indicator/SH.XPD.PUBL.ZS> (Accessed 21 August 2014).

World Bank. 2014b. Net ODA received (\% of GNI). Available at <http://data.worldbank.org/indicator/DT.ODA.ODAT.GN.ZS> (Accessed 21 August 2014)

Yang, Z., Norton, E. C., \& Stearns, S. C. (2003). Longevity and health care expenditures the real reasons older people spend more. The Journals of Gerontology Series B: Psychological Sciences and Social Sciences 58(1): S2-S10.

http://dx.doi.org/10.1093/geronb/58.1.S2 


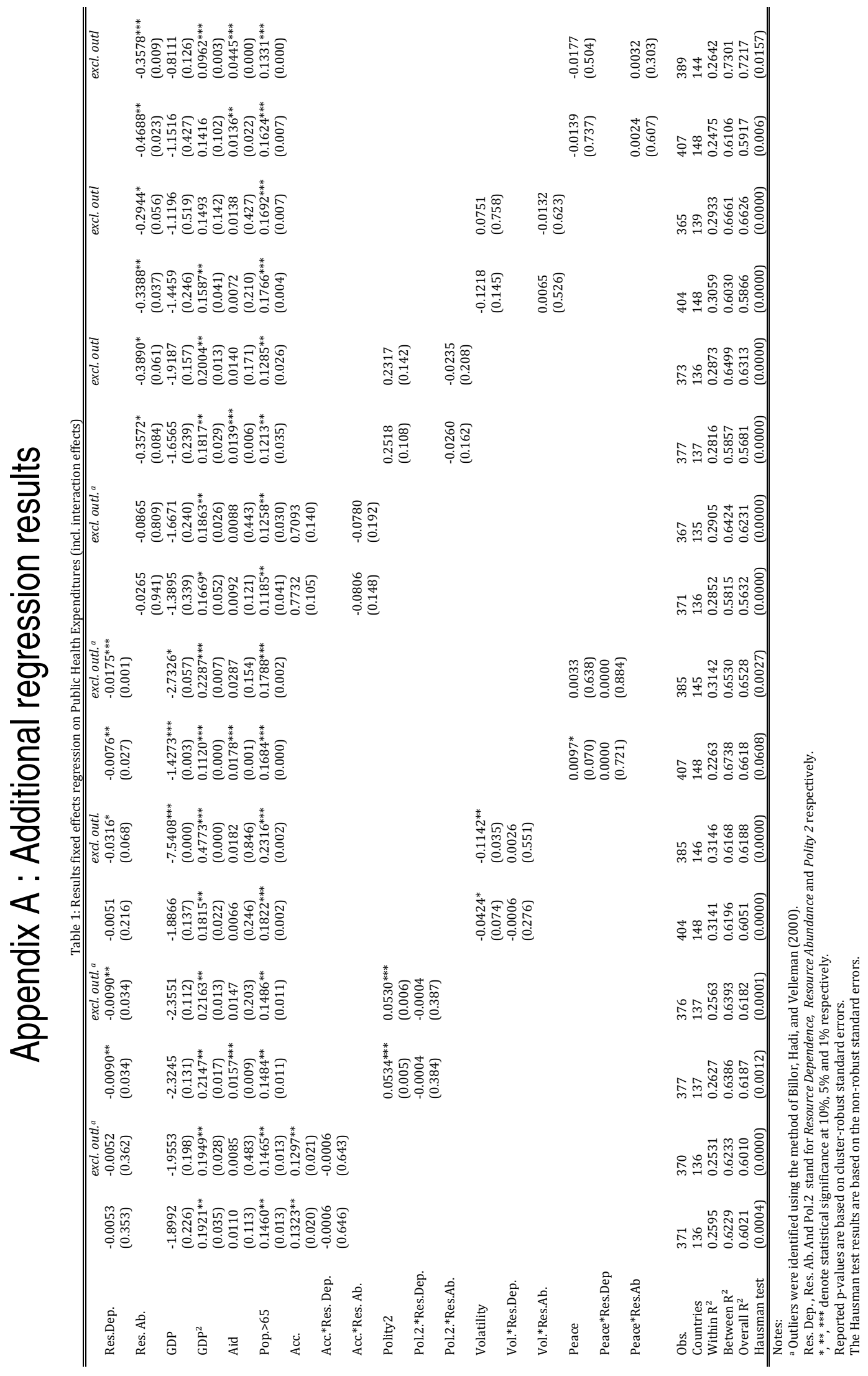


Table 2: Results random effects regressions on Public Health Expenditures (incl. interaction effects)

\begin{tabular}{|c|c|c|c|c|}
\hline Res. Dep. & $\begin{array}{l}-0.0041 \\
(0.454)\end{array}$ & $\begin{array}{l}-0.0070 \\
(0.195)\end{array}$ & & excl.outl. \\
\hline Res. Ab. & & & $\begin{array}{l}0.0228 \\
(0.769)\end{array}$ & $\begin{array}{l}-0.1063 \\
(0.367)\end{array}$ \\
\hline GDP & $\begin{array}{l}-1.4743^{* * *} \\
(0.004)\end{array}$ & $\begin{array}{l}-1.779 * * * \\
(0.004)\end{array}$ & $\begin{array}{l}-0.5758 \\
(0.281)\end{array}$ & $\begin{array}{l}-0.42271 \\
(0.422)\end{array}$ \\
\hline $\mathrm{GDP}^{2}$ & $\begin{array}{l}0.1199^{* * *} \\
(0.000)\end{array}$ & $\begin{array}{l}0.1381^{* * *} \\
(0.000)\end{array}$ & $\begin{array}{l}0.0708^{* *} \\
(0.036)\end{array}$ & $\begin{array}{l}0.0765^{* *} \\
(0.015)\end{array}$ \\
\hline Aid & $\begin{array}{l}0.0186^{* * * *} \\
(0.002)\end{array}$ & $\begin{array}{l}0.0346^{* * * *} \\
(0.009)\end{array}$ & $\begin{array}{l}0.0174^{* * *} \\
(0.001)\end{array}$ & $\begin{array}{l}0.0454^{* * *} \\
(0.000)\end{array}$ \\
\hline Pop. > 65 & $\begin{array}{l}0.1526^{* * *} \\
(0.000)\end{array}$ & $\begin{array}{l}0.1488^{* * *} \\
(0.000)\end{array}$ & $\begin{array}{l}0.1626^{* * * *} \\
(0.000)\end{array}$ & $\begin{array}{l}0.1214^{* * *} \\
(0.000)\end{array}$ \\
\hline Africa & $\begin{array}{l}0.0864 \\
(0.804)\end{array}$ & $\begin{array}{l}0.2419 \\
(0.494)\end{array}$ & $\begin{array}{l}4.9266^{* *} \\
(0.013)\end{array}$ & $\begin{array}{l}4.2365^{* *} \\
(0.039)\end{array}$ \\
\hline Africa*Res.Dep. & $\begin{array}{l}-0.0082 \\
(0.253)\end{array}$ & $\begin{array}{l}-0.0159^{* *} \\
(0.042)\end{array}$ & & \\
\hline Africa*Res.Ab. & & & $\begin{array}{l}-0.5948^{* * *} \\
(0.010)\end{array}$ & $\begin{array}{l}-0.5207^{* *} \\
(0.028)\end{array}$ \\
\hline Asia & $\begin{array}{l}-1.1212^{* * *} \\
(0.001)\end{array}$ & $\begin{array}{l}-1.0007^{* * * *} \\
(0.009)\end{array}$ & $\begin{array}{l}-0.6927 \\
(0.706)\end{array}$ & $\begin{array}{l}2.3146 \\
(0.102)\end{array}$ \\
\hline Asia*Res.Dep & $\begin{array}{l}0.0033 \\
(0.624)\end{array}$ & $\begin{array}{l}-0.0012 \\
(0.891)\end{array}$ & & \\
\hline Asia*Res.Ab. & & & $\begin{array}{l}-0.0210 \\
(0.918)\end{array}$ & $\begin{array}{l}-0.3570^{* *} \\
(0.022)\end{array}$ \\
\hline Obs. & 407 & 394 & 407 & 397 \\
\hline Countries & 148 & 147 & 148 & 146 \\
\hline Within $\mathrm{R}^{2}$ & 0.2317 & 0.2966 & 0.2480 & 0.2714 \\
\hline Between $\mathrm{R}^{2}$ & 0.7103 & 0.7100 & 0.6987 & 0.7391 \\
\hline Overall $\mathrm{R}^{2}$ & 0.6957 & 0.7143 & 0.6850 & 0.7214 \\
\hline
\end{tabular}

Res. Dep. and Res. Ab. stand for Resource Dependence and Resource Abundance.

$*, * *, * * *$ denote statistical significance at $10 \%, 5 \%$ and $1 \%$ respectively.

Reported p-values are based on cluster-robust standard errors. 
Table 3: Results OLS regressions on Public Health Expenditures (2004-2009)

\begin{tabular}{|c|c|c|c|c|c|c|c|c|}
\hline Res. Dep & $\begin{array}{l}-0.0064^{* *} \\
(0.037)\end{array}$ & $\begin{array}{l}\text { excl. outl. }{ }^{a} \\
-0.0077^{* *} \\
(0.019)\end{array}$ & $\begin{array}{l}-0.0049 \\
(0.358)\end{array}$ & $\begin{array}{l}\text { excl. outl. }{ }^{a} \\
-0.0070 \\
(0.219)\end{array}$ & & excl. outl. ${ }^{a}$ & & $\overline{\text { excl. outl. }{ }^{a}}$ \\
\hline Res. Ab. & & & & & $\begin{array}{l}0.0524 \\
(0.748)\end{array}$ & $\begin{array}{l}0.0689 \\
(0.660)\end{array}$ & $\begin{array}{l}0.0624 \\
(0.713)\end{array}$ & $\begin{array}{l}0.0749 \\
(0.647)\end{array}$ \\
\hline GDP & $\begin{array}{l}-2.0054^{* *} \\
(0.012)\end{array}$ & $\begin{array}{l}-0.2820 \\
(0.707)\end{array}$ & $\begin{array}{l}-1.9382^{* *} \\
(0.017)\end{array}$ & $\begin{array}{l}-0.2560 \\
(0.741)\end{array}$ & $\begin{array}{l}-2.1515^{* * *} \\
(0.007)\end{array}$ & $\begin{array}{l}-0.6488 \\
(0.365)\end{array}$ & $\begin{array}{l}0.0624^{* *} \\
(0.012)\end{array}$ & $\begin{array}{l}-0.6074 \\
(0.402)\end{array}$ \\
\hline $\mathrm{GDP}^{2}$ & $\begin{array}{l}0.1485^{* * *} \\
(0.002)\end{array}$ & $\begin{array}{l}0.0575 \\
(0.203)\end{array}$ & $\begin{array}{l}0.1448^{* * * *} \\
(0.003)\end{array}$ & $\begin{array}{l}0.0561 \\
(0.227)\end{array}$ & $\begin{array}{l}0.1548^{* * *} \\
(0.001)\end{array}$ & $\begin{array}{l}0.0756^{*} \\
(0.082)\end{array}$ & $\begin{array}{l}0.1506^{* * * *} \\
(0.002)\end{array}$ & $\begin{array}{l}0.0734^{*} \\
(0.097)\end{array}$ \\
\hline Aid & $\begin{array}{l}0.0288 \\
(0.193)\end{array}$ & $\begin{array}{l}0.1280^{* * * *} \\
(0.000)\end{array}$ & $\begin{array}{l}0.0299 \\
(0.174)\end{array}$ & $\begin{array}{l}0.1283^{* * *} \\
(0.000)\end{array}$ & $\begin{array}{l}0.0234 \\
(0.262)\end{array}$ & $\begin{array}{l}0.1127^{* * * *} \\
(0.000)\end{array}$ & $\begin{array}{l}0.0234 \\
(0.260)\end{array}$ & $\begin{array}{l}0.1122^{* * *} \\
(0.000)\end{array}$ \\
\hline Pop. $>65$ & $\begin{array}{l}0.1780^{* * *} \\
(0.000)\end{array}$ & $\begin{array}{l}0.1837^{* * * *} \\
(0.000)\end{array}$ & $\begin{array}{l}0.1811^{* * * *} \\
(0.000)\end{array}$ & $\begin{array}{l}0.1850^{* * * *} \\
(0.000)\end{array}$ & $\begin{array}{l}0.1982^{* * * *} \\
(0.000)\end{array}$ & $\begin{array}{l}0.2078^{* * * *} \\
(0.000)\end{array}$ & $\begin{array}{l}0.1986^{* * * *} \\
(0.000)\end{array}$ & $\begin{array}{l}0.2080^{* * *} \\
(0.000)\end{array}$ \\
\hline EITI & $\begin{array}{l}-0.1365 \\
(0.591)\end{array}$ & $\begin{array}{l}-0.0613 \\
(0.793)\end{array}$ & $\begin{array}{l}-0.0136 \\
(0.970)\end{array}$ & $\begin{array}{l}-0.0218 \\
(0.954)\end{array}$ & $\begin{array}{l}-0.2180 \\
(0.404)\end{array}$ & $\begin{array}{l}-0.1452 \\
(0.558)\end{array}$ & $\begin{array}{l}0.7117 \\
(0.730)\end{array}$ & $\begin{array}{l}0.4207 \\
(0.836)\end{array}$ \\
\hline EITI*Res.Dep. & & & $\begin{array}{l}-0.0032 \\
(0.606)\end{array}$ & $\begin{array}{l}-0.0010 \\
(0.916)\end{array}$ & & & & \\
\hline EITI*Res.Ab. & & & & & & & $\begin{array}{l}-0.1079 \\
(0.651)\end{array}$ & $\begin{array}{l}-0.0657 \\
(0.782)\end{array}$ \\
\hline Countries & 147 & 146 & 147 & 145 & 147 & 146 & 147 & 146 \\
\hline $\mathrm{R}^{2}$ & 0.6456 & 63.81 & 0.6462 & 53.81 & 55.39 & 65.35 & 47.14 & 55.66 \\
\hline
\end{tabular}




\section{APPENDIX B : LIST OF COUNTRIES}

\begin{tabular}{|c|c|c|c|}
\hline Albania & Finland & Moldova & Turkey \\
\hline Algeria & France & Mongolia & Uganda \\
\hline Angola & Gabon & Morocco & Ukraine \\
\hline Argentina & Gambia, The & Mozambique & United Arab Emirates \\
\hline Armenia & Georgia & Namibia & United Kingdom \\
\hline Australia & Germany & Nepal & United States \\
\hline Austria & Ghana & Netherlands & Uruguay \\
\hline Azerbaijan & Greece & New Zealand & Uzbekistan \\
\hline Bahrain & Grenada & Nicaragua & Vanuatu \\
\hline Bangladesh & Guatemala & Niger & Venezuela, RB \\
\hline Belarus & Guinea & Nigeria & Vietnam \\
\hline Belgium & Guinea-Bissau & Norway & Zambia \\
\hline Belize & Guyana & Oman & \\
\hline Benin & Haiti & Pakistan & \\
\hline Bhutan & Honduras & Panama & \\
\hline Bolivia & Hungary & Papua New Guinea & \\
\hline Botswana & Iceland & Peru & \\
\hline Brazil & India & Philippines & \\
\hline Brunei Darussalam & Indonesia & Poland & \\
\hline Bulgaria & Iran, Islamic Rep. & Portugal & \\
\hline Burkina Faso & Ireland & Romania & \\
\hline Burundi & Israel & Russian Federation & \\
\hline Cambodia & Italy & Rwanda & \\
\hline Cameroon & Jamaica & Saudi Arabia & \\
\hline Canada & Japan & Senegal & \\
\hline Central African Republic & Jordan & Seychelles & \\
\hline Chad & Kenya & Sierra Leone & \\
\hline Chile & Korea, Rep. & Singapore & \\
\hline China & Kuwait & Slovak Republic & \\
\hline Colombia & Kyrgyz Republic & South Africa & \\
\hline Comoros & Lao PDR & Spain & \\
\hline Congo, Dem. Rep. & Latvia & Sri Lanka & \\
\hline Congo, Rep. & Lesotho & St. Kitts and Nevis & \\
\hline Costa Rica & Liberia & St. Lucia & \\
\hline Cote d'Ivoire & Lithuania & St. Vincent and the Grenadines & \\
\hline Croatia & Luxembourg & Sudan & \\
\hline Cyprus & Macedonia, FYR & Swaziland & \\
\hline Czech Republic & Madagascar & Sweden & \\
\hline Denmark & Malawi & Switzerland & \\
\hline Dominica & Malaysia & Syrian Arab Republic & \\
\hline Dominican Republic & Maldives & Tajikistan & \\
\hline Ecuador & Mali & Thailand & \\
\hline Egypt, Arab Rep. & Malta & Togo & \\
\hline El Salvador & Mauritania & Tonga & \\
\hline Ethiopia & Mauritius & Trinidad and Tobago & \\
\hline Fiji & Mexico & Tunisia & \\
\hline
\end{tabular}




\section{TABLES}

Table 1: Descriptive statistics

\begin{tabular}{|c|c|c|c|c|c|c|c|c|c|}
\hline & & \multirow[t]{2}{*}{ Obs. } & \multirow[t]{2}{*}{ Countries } & \multirow[t]{2}{*}{ Mean } & \multicolumn{3}{|c|}{ Std. Dev. } & \multirow[t]{2}{*}{ Minimum } & \multirow[t]{2}{*}{ Maximum } \\
\hline & & & & & Overall & Between & Within & & \\
\hline 3.1 & Public Health Expenditures & 560 & 188 & 3.6017 & 2.2432 & 2.1848 & 0.5403 & 0.0385 & 16.2833 \\
\hline 3.2 .1 & 1 Resource Abundance & 423 & 153 & 8.6775 & 1.4728 & 1.4224 & 0.2079 & 0.6857 & 12.2696 \\
\hline 3.2 .1 & 2 Resource Dependence & 423 & 153 & 28.6443 & 31.9413 & 30.3933 & 9.5926 & 0 & 243.9587 \\
\hline 3.2 .2 & GDP & 579 & 199 & 8.0548 & 1.6706 & 1.6677 & 0.1604 & 3.9129 & 11.7488 \\
\hline 3.2 .3 & Aid & 642 & 214 & 5.3876 & 10.0595 & 8.5820 & 5.2700 & -0.1540 & 110.4498 \\
\hline 3.2 .4 & Pop. $>65$ & 582 & 194 & 7.0250 & 4.6957 & 4.6689 & 0.5717 & 0.5679 & 21.0439 \\
\hline 3.2 .5 & 1 Accountability & 473 & 162 & 4.7912 & 2.0721 & 2.0048 & 0.5578 & 1 & 7 \\
\hline 3.2 .5 & 2 Volatility & 570 & 197 & 4.3392 & 4.5817 & 3.8219 & 2.6273 & 0.4742 & 43.6227 \\
\hline 3.2 .5 & 3 Polity 2 & 480 & 163 & 3.1133 & 6.5191 & 6.3552 & 1.5229 & -10 & 10 \\
\hline 3.2 .5 & 4 Peace & 642 & 214 & 34.3914 & 24.1479 & 23.6996 & 4.8170 & 0 & 61.5 \\
\hline \multirow[t]{2}{*}{3.2 .6} & ELF1 & & & 15.9519 & 18.1370 & 18.1669 & 0 & 0 & 64.6600 \\
\hline & Herfindahl & 413 & 150 & 0.4089 & 0.1656 & 0.1641 & 0.0497 & 0.1445 & 0.9986 \\
\hline
\end{tabular}


Table 2: Results fixed effects regressions on Public Health Expenditures

\begin{tabular}{|c|c|c|c|c|c|c|c|c|}
\hline Res. Dep. & $\begin{array}{l}-0.0102^{* * *} \\
(0.010)\end{array}$ & $\begin{array}{l}\text { excl. outl. } \\
-0.0208^{* * *} \\
(0.000)\end{array}$ & $\begin{array}{l}-0.0087^{* *} \\
(0.039)\end{array}$ & $\begin{array}{l}\text { excl. outl. } \\
-0.0185^{* * *} \\
(0.001)\end{array}$ & $\begin{array}{l}-0.0093^{* *} \\
(0.024)\end{array}$ & $\begin{array}{l}\text { excl. outl. } \\
-0.0205^{* * *} \\
(0.000)\end{array}$ & $\begin{array}{l}-0.0095^{* *} \\
(0.023)\end{array}$ & $\begin{array}{l}\text { excl.outl. } \\
-0.0207^{* * *} \\
(0.000)\end{array}$ \\
\hline GDP & & & $\begin{array}{l}-2.7465^{*} \\
(0.091)\end{array}$ & $\begin{array}{l}-3.1114^{*} \\
(0.069)\end{array}$ & $\begin{array}{l}-2.3393 \\
(0.134)\end{array}$ & $\begin{array}{l}-3.5140^{* *} \\
(0.017)\end{array}$ & $\begin{array}{l}-1.9097 \\
(0.210)\end{array}$ & $\begin{array}{l}-3.210^{* *} \\
(0.026)\end{array}$ \\
\hline $\mathrm{GDP}^{2}$ & & & $\begin{array}{l}0.2548^{* * *} \\
(0.008)\end{array}$ & $\begin{array}{l}0.2727^{* * *} \\
(0.007)\end{array}$ & $\begin{array}{l}0.2333^{* *} \\
(0.012)\end{array}$ & $\begin{array}{l}0.2966^{* * *} \\
(0.001)\end{array}$ & $\begin{array}{l}0.1861^{* *} \\
(0.036)\end{array}$ & $\begin{array}{l}0.2552^{* * *} \\
(0.002)\end{array}$ \\
\hline Aid & & & & & $\begin{array}{l}0.0156^{* * *} \\
(0.009)\end{array}$ & $\begin{array}{l}0.0202 \\
(0.240)\end{array}$ & $\begin{array}{l}0.0146^{* *} \\
(0.017)\end{array}$ & $\begin{array}{l}0.0171 \\
(0.428)\end{array}$ \\
\hline Pop. $>65$ & & & & & & & $\begin{array}{l}0.1746^{* * *} \\
(0.002)\end{array}$ & $\begin{array}{l}0.1832^{* * *} \\
(0.001)\end{array}$ \\
\hline Obs. & 417 & 407 & 413 & 402 & 413 & 398 & 407 & 392 \\
\hline Countries & 150 & 148 & 150 & 148 & 150 & 148 & 148 & 147 \\
\hline Within $\mathrm{R}^{2}$ & 0.0481 & 0.1056 & 0.1949 & 0.2416 & 0.2114 & 0.2659 & 0.2474 & 0.3075 \\
\hline Between $\mathrm{R}^{2}$ & 0.1922 & 0.2802 & 0.5182 & 0.5383 & 0.5246 & 0.5458 & 0.6226 & 0.6260 \\
\hline Overall $\mathrm{R}^{2}$ & 0.1742 & 0.2712 & 0.5009 & 0.5304 & 0.5077 & 0.5414 & 0.6037 & 0.6311 \\
\hline Hausman & $(0.0017)$ & $(0.0149)$ & $(0.0188)$ & $(0.0149)$ & $(0.0048)$ & $(0.0014)$ & $(0.0002)$ & $(0.0000)$ \\
\hline
\end{tabular}

Notes:

Res. Dep. stands for Resource Dependence.

$*, * *, * *$ denote statistical significance at $10 \%, 5 \%$ and $1 \%$ respectively.

Reported p-values are based on cluster-robust standard errors.

The Hausman test results are based on the non-robust standard errors. 
Table 3: Results fixed effects regressions on Public Health Expenditures

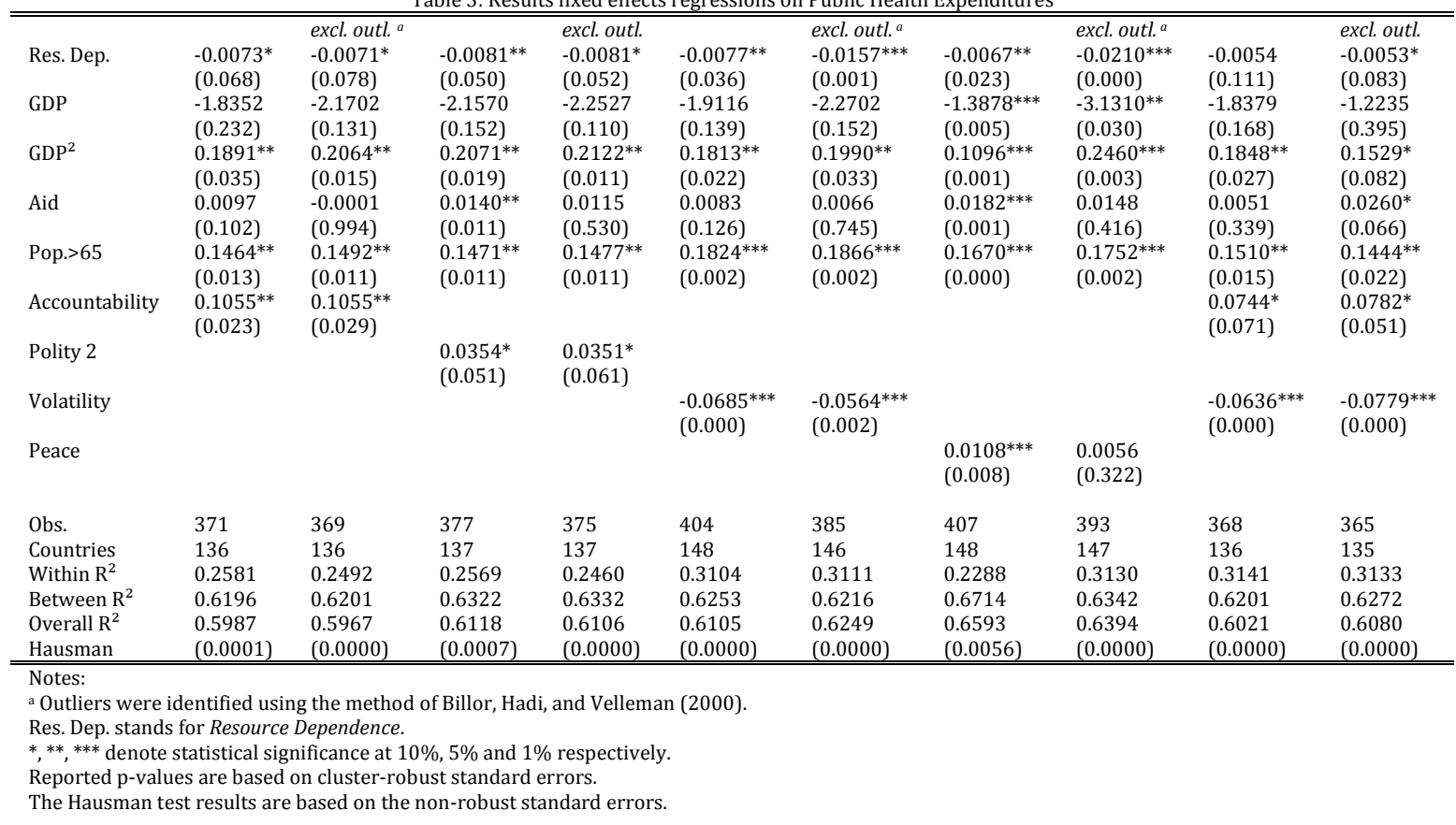


Table 4: Results random effects regressions on Public Health Expenditures

\begin{tabular}{|c|c|c|c|c|}
\hline Res. Dep. & $\begin{array}{l}-0.0062^{* *} \\
(0.041)\end{array}$ & $\begin{array}{l}\text { excl. outl. } \\
-0.0149^{* * *} \\
(0.000)\end{array}$ & $\begin{array}{l}-0.0067^{* *} \\
(0.027)\end{array}$ & $\begin{array}{l}\text { excl. outl. } \\
-0.0147^{* * *} \\
(0.000)\end{array}$ \\
\hline GDP & $\begin{array}{l}-1.2045^{* *} \\
(0.015)\end{array}$ & $\begin{array}{l}-1.3582^{* *} \\
(0.022)\end{array}$ & $\begin{array}{l}-1.3722^{* * *} \\
(0.005)\end{array}$ & $\begin{array}{l}-1.4971^{* * *} \\
(0.010)\end{array}$ \\
\hline $\mathrm{GDP}^{2}$ & $\begin{array}{l}0.1031^{* * *} \\
(0.001)\end{array}$ & $\begin{array}{l}0.1125 \\
(0.002)\end{array}$ & $\begin{array}{l}0.1136^{* * *} \\
(0.000)\end{array}$ & $\begin{array}{l}0.1210^{* * *} \\
(0.001)\end{array}$ \\
\hline Aid & $\begin{array}{l}0.0194^{* * *} \\
(0.001)\end{array}$ & $\begin{array}{l}0.0400^{* * *} \\
(0.001)\end{array}$ & $\begin{array}{l}0.0184^{* * *} \\
(0.002)\end{array}$ & $\begin{array}{l}0.0363^{* * *} \\
(0.005)\end{array}$ \\
\hline Pop. $>65$ & $\begin{array}{l}0.1645^{* * *} \\
(0.000)\end{array}$ & $\begin{array}{l}0.1596^{* * *} \\
(0.000)\end{array}$ & $\begin{array}{l}0.1484^{* * *} \\
(0.000)\end{array}$ & $\begin{array}{l}0.1384^{* * *} \\
(0.000)\end{array}$ \\
\hline ELF1 & $\begin{array}{l}-0.0109^{*} \\
(0.066)\end{array}$ & $\begin{array}{l}-0.0080 \\
(0.203)\end{array}$ & & \\
\hline Africa & & & $\begin{array}{l}-0.2278 \\
(0.396)\end{array}$ & $\begin{array}{l}-0.2607 \\
(0.338)\end{array}$ \\
\hline Asia & & & $\begin{array}{l}-0.9910^{* * *} \\
(0.000)\end{array}$ & $\begin{array}{l}-0.9805^{* * *} \\
(0.001)\end{array}$ \\
\hline Obs. & 407 & 392 & 407 & 394 \\
\hline Countries & 148 & 146 & 148 & 147 \\
\hline Within $\mathrm{R}^{2}$ & 0.2226 & 0.2774 & 0.2257 & 0.2897 \\
\hline Between $R^{2}$ & 0.6714 & 0.6812 & 0.7015 & 0.7020 \\
\hline Overall $\mathrm{R}^{2}$ & 0.6539 & 0.6774 & 0.6852 & 0.7078 \\
\hline
\end{tabular}

\section{Notes:}

Res. Dep. stands for Resource Dependence.

$*, * *, * *$ denote statistical significance at $10 \%, 5 \%$ and $1 \%$ respectively. Reported p-values are based on cluster-robust standard errors. 
Table 5 : Results fixed effects regressions on Public Health Expenditures

\begin{tabular}{|c|c|c|c|c|c|c|c|c|}
\hline Res. Ab. & $\begin{array}{l}-0.3878^{* *} \\
(0.020)\end{array}$ & $\begin{array}{l}\text { excl. outl. } \\
-0.4217^{* *} \\
(0.014)\end{array}$ & $\begin{array}{l}-0.3411^{* *} \\
(0.037)\end{array}$ & $\begin{array}{l}\text { excl. outl. } \\
-0.3782^{* *} \\
(0.026)\end{array}$ & $\begin{array}{l}-0.3576^{* *} \\
(0.030)\end{array}$ & $\begin{array}{l}\text { excl. outl. } \\
-0.4502^{* * *} \\
(0.006)\end{array}$ & $\begin{array}{l}-0.4045^{* *} \\
(0.014)\end{array}$ & $\begin{array}{l}\text { excl.outl. } \\
-0.4892^{* * *} \\
(0.002)\end{array}$ \\
\hline GDP & & & $\begin{array}{r}-2.0175 \\
(0.198)\end{array}$ & $\begin{array}{l}-2.2636 \\
(0.150)\end{array}$ & $\begin{array}{l}-1.5864 \\
(0.289)\end{array}$ & $\begin{array}{l}-2.2441 \\
(0.131)\end{array}$ & $\begin{array}{l}-1.2041 \\
(0.405)\end{array}$ & $\begin{array}{l}-1.8832 \\
(0.178)\end{array}$ \\
\hline $\mathrm{GDP}^{2}$ & & & $\begin{array}{l}0.2151^{* *} \\
(0.022)\end{array}$ & $\begin{array}{l}0.2325^{* *} \\
(0.013)\end{array}$ & $\begin{array}{l}0.1923^{* *} \\
(0.033)\end{array}$ & $\begin{array}{l}0.2333^{* * *} \\
(0.009)\end{array}$ & $\begin{array}{l}0.1494^{*} \\
(0.080)\end{array}$ & $\begin{array}{l}0.1922^{* *} \\
(0.018)\end{array}$ \\
\hline Aid & & & & & $\begin{array}{l}0.0146^{* * *} \\
(0.008)\end{array}$ & $\begin{array}{l}0.0224 \\
(0.141)\end{array}$ & $\begin{array}{l}0.0137^{* *} \\
(0.016)\end{array}$ & $\begin{array}{l}0.0278^{*} \\
(0.071)\end{array}$ \\
\hline Pop. $>65$ & & & & & & & $\begin{array}{l}0.1675^{* * *} \\
(0.004)\end{array}$ & $\begin{array}{l}0.1738^{* * *} \\
(0.004)\end{array}$ \\
\hline Obs. & 417 & 411 & 413 & 407 & 413 & 402 & 407 & 397 \\
\hline Countries & 150 & 148 & 150 & 148 & 150 & 148 & 148 & 146 \\
\hline Within $\mathrm{R}^{2}$ & 0.0318 & 0.0359 & 0.1873 & 0.1982 & 0.2018 & 0.2224 & 0.2418 & 0.2684 \\
\hline Between $\mathrm{R}^{2}$ & 0.0684 & 0.0728 & 0.4945 & 0.5668 & 0.4989 & 0.5803 & 0.5911 & 0.6722 \\
\hline Overall $\mathrm{R}^{2}$ & 0.0614 & 0.0634 & 0.4783 & 0.5502 & 0.4830 & 0.5672 & 0.5717 & 0.6567 \\
\hline Hausman & $(0.0000)$ & $(0.0000)$ & $(0.0042)$ & $(0.0017)$ & $(0.0017)$ & $(0.0134)$ & $(0.0000)$ & $(0.0001)$ \\
\hline
\end{tabular}

Notes:

Res. Ab. stands for Resource Abundance

$*, * *, * * *$ denote statistical significance at $10 \%, 5 \%$ and $1 \%$ respectively.

Reported p-values are based on cluster-robust standard errors.

The Hausman test results are based on the non-robust standard errors. 
Table 6 : Results fixed effects regressions on Public Health Expenditures

\begin{tabular}{|c|c|c|c|c|c|c|c|c|c|c|}
\hline & & excl. outl. ${ }^{a}$ & & excl. outl. a & & excl. outl. & & excl. outl. & & excl. outl. . \\
\hline Res. Ab. & $\begin{array}{l}-0.4458^{* * *} \\
(0.008)\end{array}$ & $\begin{array}{l}-0.4624^{* * *} \\
(0.006)\end{array}$ & $\begin{array}{l}-0.4752^{* * *} \\
(0.006)\end{array}$ & $\begin{array}{l}-0.4960^{* * *} \\
(0.004)\end{array}$ & $\begin{array}{l}-0.3140^{* *} \\
(0.043)\end{array}$ & $\begin{array}{l}-0.3705^{* *} \\
(0.017)\end{array}$ & $\begin{array}{l}-0.3942 * * \\
(0.016)\end{array}$ & $\begin{array}{l}-0.3637^{* * *} \\
(0.001)\end{array}$ & $\begin{array}{l}-0.3560^{* *} \\
(0.027)\end{array}$ & $\begin{array}{l}-0.3732^{* *} \\
(0.021)\end{array}$ \\
\hline GDP & $\begin{array}{l}-1.3952 \\
(0.346)\end{array}$ & $\begin{array}{l}-2.0737 \\
(0.131)\end{array}$ & $\begin{array}{l}-1.6349 \\
(0.252)\end{array}$ & $\begin{array}{l}-2.0813 \\
(0.121)\end{array}$ & $\begin{array}{l}-1.3748 \\
(0.275)\end{array}$ & $\begin{array}{l}-1.3179 \\
(0.364)\end{array}$ & $\begin{array}{l}-1.1634 \\
(0.421)\end{array}$ & $\begin{array}{l}-0.7915 \\
(0.147)\end{array}$ & $\begin{array}{l}-1.6012 \\
(0.229)\end{array}$ & $\begin{array}{l}-1.3562 \\
(0.330)\end{array}$ \\
\hline $\mathrm{GDP}^{2}$ & $\begin{array}{l}0.1673^{*} \\
(0.055)\end{array}$ & $\begin{array}{l}0.2078^{* * *} \\
(0.010)\end{array}$ & $\begin{array}{l}0.1808^{* *} \\
(0.032)\end{array}$ & $\begin{array}{l}0.2095^{* * *} \\
(0.008)\end{array}$ & $\begin{array}{l}0.1543^{* *} \\
(0.049)\end{array}$ & $\begin{array}{l}0.1580 \\
(0.071)\end{array}$ & $\begin{array}{l}0.1418^{*} \\
(0.100)\end{array}$ & $\begin{array}{l}0.0923^{* * *} \\
(0.006)\end{array}$ & $\begin{array}{l}0.1753^{* *} \\
(0.036)\end{array}$ & $\begin{array}{l}0.1685^{* *} \\
(0.049)\end{array}$ \\
\hline Aid & $\begin{array}{l}0.0100^{*} \\
(0.088)\end{array}$ & $\begin{array}{l}-0.0003 \\
(0.986)\end{array}$ & $\begin{array}{l}0.0140^{* * *} \\
(0.008)\end{array}$ & $\begin{array}{l}0.0105 \\
(0.546)\end{array}$ & $\begin{array}{l}0.0075 \\
(0.174)\end{array}$ & $\begin{array}{l}0.0300^{* *} \\
(0.030)\end{array}$ & $\begin{array}{l}0.01338^{* *} \\
(0.020)\end{array}$ & $\begin{array}{l}0.0371^{* * *} \\
(0.002)\end{array}$ & $\begin{array}{l}0.0055 \\
(0.321)\end{array}$ & $\begin{array}{l}0.0244^{*} \\
(0.075)\end{array}$ \\
\hline Pop. $>65$ & $\begin{array}{l}0.1294^{* *} \\
(0.025)\end{array}$ & $\begin{array}{l}0.1393^{* *} \\
(0.016)\end{array}$ & $\begin{array}{l}0.1300^{* *} \\
(0.024)\end{array}$ & $\begin{array}{l}0.1378^{* *} \\
(0.016)\end{array}$ & $\begin{array}{l}0.1754^{* * *} \\
(0.004)\end{array}$ & $\begin{array}{l}0.1741^{* * *} \\
(0.005)\end{array}$ & $\begin{array}{l}0.1588^{* * *} \\
(0.007)\end{array}$ & $\begin{array}{l}0.1453^{* * *} \\
(0.000)\end{array}$ & $\begin{array}{l}0.1339 * * \\
(0.030)\end{array}$ & $\begin{array}{l}0.1308^{* *} \\
(0.036)\end{array}$ \\
\hline Accountability & $\begin{array}{l}0.1023^{* *} \\
(0.018)\end{array}$ & $\begin{array}{l}0.1040^{* *} \\
(0.023)\end{array}$ & & & & & & & $\begin{array}{l}0.0725^{*} \\
(0.064)\end{array}$ & $\begin{array}{l}0.0784^{* *} \\
(0.042)\end{array}$ \\
\hline Polity 2 & & & $\begin{array}{l}0.0367^{* *} \\
(0.030)\end{array}$ & $\begin{array}{l}0.0366^{* *} \\
(0.037)\end{array}$ & & & & & & \\
\hline Volatility & & & & & $\begin{array}{l}-0.0689^{* * *} \\
(0.000)\end{array}$ & $\begin{array}{l}-0.0705^{* * *} \\
(0.000)\end{array}$ & & & $\begin{array}{l}-0.0622^{* * *} \\
(0.000)\end{array}$ & $\begin{array}{l}-0.0735^{* * *} \\
(0.000)\end{array}$ \\
\hline Peace & & & & & & & $\begin{array}{l}0.0066 \\
(0.263)\end{array}$ & $\begin{array}{l}0.0103^{* * *} \\
(0.010)\end{array}$ & & \\
\hline Obs. & 371 & 366 & 377 & 372 & 404 & 391 & 407 & 396 & 368 & 362 \\
\hline Countries & 136 & 135 & 136 & 136 & 148 & 145 & 148 & 146 & 136 & 134 \\
\hline Within $\mathrm{R}^{2}$ & 0.2744 & 0.2804 & 0.2721 & 0.2756 & 0.3050 & 0.2969 & 0.2458 & 0.2508 & 0.3265 & 0.3346 \\
\hline Between $\mathrm{R}^{2}$ & 0.5897 & 0.6608 & 0.5978 & 0.6730 & 0.6039 & 0.6719 & 0.6000 & 0.7075 & 0.5979 & 0.6654 \\
\hline Overall $\mathrm{R}^{2}$ & 0.5709 & 0.6408 & 0.5797 & 0.6538 & 0.5872 & 0.6579 & 0.5809 & 0.6957 & 0.5800 & 0.6484 \\
\hline Hausman & $(0.0000)$ & $(0.0000)$ & $(0.0000)$ & $(0.0000)$ & $(0.0000)$ & $(0.0001)$ & $(0.0001)$ & $(0.0018)$ & $(0.0014)$ & $(0.0001)$ \\
\hline
\end{tabular}

autliers were identified using the method of Billor, Hadi, and Velleman (2000)

Res. Ab. stands for Resource Abundance.

$*, * *, * *$ denote statistical significance at $10 \%, 5 \%$ and $1 \%$ respectively.

Reported p-values are based on cluster-robust standard errors.

The Hausman test results are based on the non-robust standard errors. 
Table 7: Results random effects regressions on Public Health Expenditures

\begin{tabular}{|c|c|c|c|c|}
\hline Res. Ab. & $\begin{array}{l}-0.0587 \\
(0.667)\end{array}$ & $\begin{array}{l}\text { excl. outl. } \\
-0.3443^{* * *} \\
(0.001)\end{array}$ & $\begin{array}{l}-0.0937 \\
(0.493)\end{array}$ & $\begin{array}{l}\text { excl.outl. } \\
-0.3899^{* * *} \\
(0.000)\end{array}$ \\
\hline GDP & $\begin{array}{l}-0.9731^{* *} \\
(0.042)\end{array}$ & $\begin{array}{l}-0.5344 \\
(0.308)\end{array}$ & $\begin{array}{l}-1.0864^{* *} \\
(0.029)\end{array}$ & $\begin{array}{l}-0.7435 \\
(0.168)\end{array}$ \\
\hline $\mathrm{GDP}^{2}$ & $\begin{array}{l}0.0925^{* * *} \\
(0.003)\end{array}$ & $\begin{array}{l}0.0811^{* *} \\
(0.012)\end{array}$ & $\begin{array}{l}0.1006^{* * *} \\
(0.001)\end{array}$ & $\begin{array}{l}0.0947^{* * *} \\
(0.004)\end{array}$ \\
\hline Aid & $\begin{array}{l}0.0175^{* * *} \\
(0.001)\end{array}$ & $\begin{array}{l}0.0476^{* * *} \\
(0.000)\end{array}$ & $\begin{array}{l}0.0166^{* * *} \\
(0.002)\end{array}$ & $\begin{array}{l}0.0450^{* * *} \\
(0.000)\end{array}$ \\
\hline Pop. $>65$ & $\begin{array}{l}0.1685^{* * *} \\
(0.000)\end{array}$ & $\begin{array}{l}0.1493^{* * *} \\
(0.000)\end{array}$ & $\begin{array}{l}0.1540^{* * *} \\
(0.000)\end{array}$ & $\begin{array}{l}0.1223^{* * *} \\
(0.000)\end{array}$ \\
\hline ELF1 & $\begin{array}{l}-0.0131^{* *} \\
(0.037)\end{array}$ & $\begin{array}{l}-0.0068 \\
(0.197)\end{array}$ & & \\
\hline Africa & & & $\begin{array}{l}-0.2213 \\
(0.405)\end{array}$ & $\begin{array}{l}-0.3921 \\
(0.146)\end{array}$ \\
\hline Asia & & & $\begin{array}{l}-1.0027^{* * *} \\
(0.000)\end{array}$ & $\begin{array}{l}-0.9663^{* * *} \\
(0.000)\end{array}$ \\
\hline Obs. & 407 & 397 & 407 & 397 \\
\hline Countries & 148 & 146 & 148 & 146 \\
\hline Within $\mathrm{R}^{2}$ & 0.1947 & 0.2398 & 0.2045 & 0.2432 \\
\hline Between $\mathrm{R}^{2}$ & 0.6720 & 0.7050 & 0.6962 & 0.7360 \\
\hline Overall $R^{2}$ & 0.6524 & 0.6886 & 0.6781 & 0.7178 \\
\hline
\end{tabular}


Table 8: Results fixed effects regression on Public Health Expenditures (incl. time fixed effects)

\begin{tabular}{|c|c|c|c|c|}
\hline Resource Dependence & $\begin{array}{l}-0.0101^{* * *} \\
(0.010)\end{array}$ & $\begin{array}{l}\text { excl. outl. } \\
-0.0211 \\
(0.000)\end{array}$ & & excl. outl. \\
\hline Resource Abundance & & & $\begin{array}{l}-0.4252^{* * *} \\
(0.006)\end{array}$ & $\begin{array}{l}-0.5146^{* * *} \\
(0.001)\end{array}$ \\
\hline GDP & $\begin{array}{l}-2.1689 \\
(0.128)\end{array}$ & $\begin{array}{l}-3.1956^{* *} \\
(0.018)\end{array}$ & $\begin{array}{l}-1.2526 \\
(0.351)\end{array}$ & $\begin{array}{l}-1.8086 \\
(0.168)\end{array}$ \\
\hline $\mathrm{GDP}^{2}$ & $\begin{array}{l}0.1362 \\
(0.107)\end{array}$ & $\begin{array}{l}0.1959^{* *} \\
(0.012)\end{array}$ & $\begin{array}{l}0.0922 \\
(0.252)\end{array}$ & $\begin{array}{l}0.1302^{*} \\
(0.089)\end{array}$ \\
\hline Aid & $\begin{array}{l}0.0189^{* * *} \\
(0.001)\end{array}$ & $\begin{array}{l}0.0273^{* *} \\
(0.040)\end{array}$ & $\begin{array}{l}0.0185^{* * *} \\
(0.001)\end{array}$ & $\begin{array}{l}0.0320^{* *} \\
(0.013)\end{array}$ \\
\hline Pop. $>65$ & $\begin{array}{l}0.0832 \\
(0.181)\end{array}$ & $\begin{array}{l}0.0875 \\
(0.158)\end{array}$ & $\begin{array}{l}0.0824 \\
(0.194)\end{array}$ & $\begin{array}{l}0.0930 \\
(0.140)\end{array}$ \\
\hline Time fixed effects & & & & \\
\hline $2000-2004$ & $\begin{array}{l}0.2736^{* * *} \\
(0.000)\end{array}$ & $\begin{array}{l}0.2821^{* * *} \\
(0.000)\end{array}$ & $\begin{array}{l}0.3038^{* * *} \\
(0.000)\end{array}$ & $\begin{array}{l}0.3024^{* * *} \\
(0.000)\end{array}$ \\
\hline 2005-2009 & $\begin{array}{l}0.5191^{* * *} \\
(0.000)\end{array}$ & $\begin{array}{l}0.4954^{* * *} \\
(0.000)\end{array}$ & $\begin{array}{l}0.4914^{* * *} \\
(0.000)\end{array}$ & $\begin{array}{l}0.4722^{* * *} \\
(0.000)\end{array}$ \\
\hline Obs. & 407 & 392 & 407 & 396 \\
\hline Countries & 148 & 146 & 148 & 146 \\
\hline Within $\mathrm{R}^{2}$ & 0.3360 & 0.3888 & 0.3256 & 0.3462 \\
\hline Between $\mathrm{R}^{2}$ & 0.4722 & 0.4446 & 0.2792 & 0.3980 \\
\hline Overall $\mathrm{R}^{2}$ & 0.4803 & 0.4814 & 0.2873 & 0.4185 \\
\hline
\end{tabular}

Notes:

$*, * *, * * *$ denote statistical significance at $10 \%, 5 \%$ and $1 \%$ respectively.

Reported p-values are based on cluster-robust standard errors. 
Table 9: Results fixed effects regressions on Public Health Expenditures

as a \% of Government Expenditure

\begin{tabular}{|c|c|c|c|c|}
\hline Resource Dependence & $\begin{array}{l}-0.0214 \\
(0.130)\end{array}$ & $\begin{array}{l}\text { excl. outl. } \\
-0.0531^{* * *} \\
(0.005)\end{array}$ & & excl. outl. \\
\hline Resource Abundance & & & $\begin{array}{l}-0.8963^{*} \\
(0.069)\end{array}$ & $\begin{array}{l}-1.1028^{* *} \\
(0.018)\end{array}$ \\
\hline GDP & $\begin{array}{l}-9.0249 \\
(0.122)\end{array}$ & $\begin{array}{l}-14.1952^{* *} \\
(0.011)\end{array}$ & $\begin{array}{l}-7.4176 \\
(0.172)\end{array}$ & $\begin{array}{l}-10.8837^{* *} \\
(0.047)\end{array}$ \\
\hline $\mathrm{GDP}^{2}$ & $\begin{array}{l}0.7068^{* *} \\
(0.029)\end{array}$ & $\begin{array}{l}0.9718^{* * *} \\
(0.002)\end{array}$ & $\begin{array}{l}0.6231^{* *} \\
(0.041)\end{array}$ & $\begin{array}{l}0.8218^{* * *} \\
(0.007)\end{array}$ \\
\hline Aid & $\begin{array}{l}0.0412 \\
(0.215)\end{array}$ & $\begin{array}{l}-0.0221 \\
(0.819)\end{array}$ & $\begin{array}{l}0.0391 \\
(0.221)\end{array}$ & $\begin{array}{l}0.0146 \\
(0.831)\end{array}$ \\
\hline Pop. $>65$ & $\begin{array}{l}0.2939^{*} \\
(0.051)\end{array}$ & $\begin{array}{l}0.3448^{* *} \\
(0.020)\end{array}$ & $\begin{array}{l}0.2781^{*} \\
(0.080)\end{array}$ & $\begin{array}{l}0.3080^{*} \\
(0.055)\end{array}$ \\
\hline Obs. & 407 & 392 & 407 & 397 \\
\hline Countries & 148 & 147 & 148 & 146 \\
\hline Within $\mathrm{R}^{2}$ & 0.1375 & 0.1905 & 0.1337 & 0.1516 \\
\hline Between $\mathrm{R}^{2}$ & 0.1982 & 0.1795 & 0.1789 & 0.2014 \\
\hline Overall $\mathrm{R}^{2}$ & 0.1795 & 0.1789 & 0.1631 & 0.1888 \\
\hline Hausman & $(0.0009)$ & $(0.0000)$ & $(0.0004)$ & $(0.0001)$ \\
\hline
\end{tabular}

$*, * *, * * *$ denote statistical significance at $10 \%, 5 \%$ and $1 \%$ respectively

Reported p-values are based on cluster-robust standard errors. 